\title{
THE CONSTITUTIONAL STATUS OF COMMERCIAL SPEECH
}

\author{
Robert Post
}

Commercial speech doctrine is presently controversial and confused. In this Lecture, Professor Robert Post offers an hypothesis about why the U.S. Supreme Court has extended First Amendment protection to commercial speech, and he then uses this hypothesis to elucidate the disputes that presently engulf the doctrine. Post argues that commercial speech is protected because of its informational function. This contrasts sharply with public discourse, which is protected to ensure forms of participation necessary to sustain democratic legitimacy. The boundaries that separate commercial speech from public discourse reflect sociological judgments about whether particular forms of communication are valued merely as information, or instead as forms of communicative action that embody democratic participation. Post explores how the Court makes these judgments. The distinction between the constitutional function of commercial speech and that of public discourse explains why the state can compel disclosures, impose overbroad regulations, and establish prior restraints within the domain of commercial speech, but not within the domain of public discourse. Post also analyzes in detail the Central Hudson test, which sets forth the standards by which the Court currently decides whether regulation of commercial speech is constitutionally justified. The test is abstract and unhelpful, because it does not reflect any particular account of the constitutional function of commercial speech. Post assesses the ways in which the Central Hudson test can be rendered consistent with the constitutional justifications for protecting commercial speech, paying particular attention to current controversies regarding whether the state can suppress truthful commercial speech in order to modify behavior.

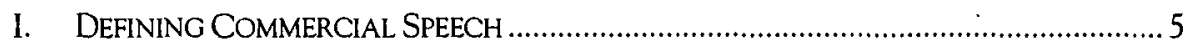

A. The Distinction Between Commercial Speech and Public Discourse...

B. The Distinction Between Commercial Speech and Commercial Communications.

II. Protecting COMMERCiAL SPEECH.

* Alexander F. and May T. Morrison Professor of Law, University of California, Berkeley, School of Law (Boalt Hall). I am most grateful for the comments and advice of Stephen Bundy, Michael Chesterman, Jesse Choper, Meir Dan-Cohen, Mel Eisenberg, Charles Fried, Daniel Halberstam, Don Herzog, David McGowan, Paul Mishkin, Steve Shiffrin, Reva Siegel, Stephen Sugarman, William Van Alstyne, Jan Vetter, Eugene Volokh, and James Weinstein. I would especially like to thank Sambhav Sankar for his indefatigable assistance. This Article is adapted from the Melville B. Nimmer Memorial Lecture, delivered at UCLA on March 9, 2000. 
A. Rules that Subordinate Commercial Speech..................................................... 26

I. Compelled Disclosures ............................................................................ 26

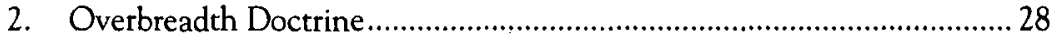

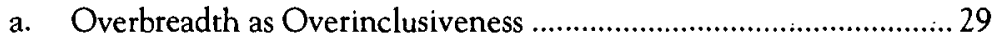

b. Overbreadth as Third-Party Standing ............................................. 31

3. Prior Restraint Doctrine........................................................................ 32

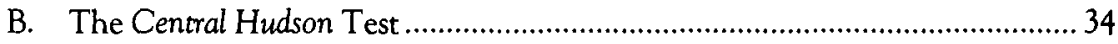

1. The Threshold Requirements ................................................................3 34

2. The First Amendment Protections ........................................................... 42

a. The Central Hudson Test and the Purpose of Government Regulations ....

(1) Ambiguity About the Purpose of Commercial Speech Doctrine.

(2) The Conflation of Commercial Speech and Public Discourse .......................................................... 46

(3) Opposition to Paternalism ......................................................... 50

b. The Central Hudson Test and the Impact of Government Regulation on Commercial Speech

\section{INTRODUCTION}

In 1976, the United States Supreme Court reversed its Iongstanding conclusion that "the Constitution imposes no ... restraint on government" regulation of "purely commercial advertising." The announcement spawned what has since become known as "commercial speech" doctrine, a notoriously unstable and contentious domain of First Amendment jurisprudence. No other realm of First Amendment law has proved as divisive. Some adamantly support the Court's original position depriving commercial speech of constitutional protection, ${ }^{2}$ whereas others are unable to discern any "philosophical or historical basis for asserting that 'commercial' speech is of 'lower value' than 'noncommercial' speech."

1. Valentine v. Chrestensen, 316 U.S. 52, 54 (1942). Chrestensen was overruled in Virginia State Board of Pharmacy v. Virginia Citizens Consumer Council, Inc., 425 U.S. 748 (1976).

2. See, e.g., Cent. Hudson Gas \& Elec. Corp. v. Pub. Serv. Comm'n, 447 U.S. 557, 598-99 (1980) (Rehnquist, J., dissenting); Va. Pharmacy, 425 U.S. at 787-90 (Rehnquist, J., dissenting); cf. Chrestensen, 316 U.S. 52; Akhil Reed Amar, Intratextualism, 112 HARV. L. REV. 748, 812-18 (1999); C. Edwin Baker, Commercial Speech: A Problem in the Theory of Freedom, 62 lowA L. REV. 1, 3 (1976); Lillian R. BeVier, The First Amendment and Political Speech: An Inquiry into the Substance and Limits of Principle, 30 STAN. L. REV. 299, 352-55 (1978); Vincent Blasi, The Pathological Perspective and the First Amendment, 85 ColuM. L. Rev. 449, 484-89 (1985); Thomas H. Jackson \& John Calvin Jeffries, Jr., Commercial Speech: Economic Due Process and the First Amendment, 65 VA. L. REV. 1, 5-6 (1979).

3. 44 Liquormart, Inc. v. Rhode Island, 517 U.S. 484, 522 (1996) (Thomas, J., concurring); see Alex Kozinski \& Stuart Banner, Who's Afraid of Commercial Speech?, 76 VA. L. REV. 627, 628 
Striving to preserve a middle ground between these two extremes, the Court has sought to fashion a doctrine that "rests heavily on 'the commonsense distinction between speech proposing a commercial transaction ... and other varieties of speech." ${ }^{\prime 4}$ This distinction is said to justify the conclusion "that 'commercial speech [enjoys] a limited measure of protection, commensurate with its subordinate position in the scale of First Amendment values,' and is subject to 'modes of regulation that might be impermissible in the realm of noncommercial expression."'5

Although the Court has persistently adjudged commercial speech to be "subordinate," it has never explained why this might be true. ${ }^{6}$ Lacking firm jurisprudential foundations, commercial speech doctrine has veered wildly between divergent and inconsistent approaches. A 1986 opinion by the Court was so solicitous of government restrictions as to suggest to commentators that commercial speech doctrine was "[l]eft for dead," whereas a 1996 opinion was so protective as to render it 'unclear why 'commercial speech' should continue to be treated as a separate category of speech isolated from general First Amendment principles."

The Court has proved susceptible to such wide swings of perspective because its "common-sense" attitude to commercial speech has systematically obscured two critical questions. These were concisely stated, appropriately enough, by William Van Alstyne in his 1995 Melville B. Nimmer Memorial Lecture: "What is 'commercial' speech, and... how, if at all, may commercial speech be treated differently, or less favorably, than other

(1990); Martin H. Redish, The First Amendment in the Marketplace: Commercial Speech and the Values of Free Expression, 39 GEO. WASH. L. REV. 429, 452-48 (1971); Rodney A. Smolla, Information, Imagery, and the First Amendment: A Case for Expansive Protection of Commercial Speech, 71 TEX. L. REV. 777, 780 (1993); cf. Kathleen M. Sullivan, Cheap Spirits, Cigarettes, and Free Speech: The Implications of 44 Liquormart, 1996 SUP. CT. REV. 123.

4. Zauderer v. Office of Disciplinary Counsel, 471 U.S. 626, 637 (1985) (quoting Ohralik v. Ohio State Bar Ass'n, 436 U.S. 447, 455-56 (1978)).

5. Bd. of Trs. v. Fox, 492 U.S. 469, 477 (1989) (alteration in original) (quoting Ohralik, 436 U.S. at 456$)$.

6. "[T]he still-dominant test devised by the Court is simply a quantitatively-reduced protection afforded to commercial speech, as compared to noncommercial speech." Daniel Halberstam, Commercial Speech, Professional Speech, and the Constitutional Status of Social Institutions, 147 U. PA. L. REV. 771, 792 (1999). For a recent spirited defense of the Court's commercial speech jurisprudence, as well as a full account of the critical dissatisfaction that it has engendered, see Nat Stern, In Defense of the Imprecise Definition of Commercial Speech, 58 MD. L. REV. 55 (1999).

7. Sullivan, supra note 3, at 123 . The opinion was Posadas de Puerto Rico Associates v. Tourism Co., 478 U.S. 328 (1986). For contemporaneous commentary, see Philip B. Kurland, Posadas de Puerto Rico v. Tourism Company: “'Twas Strange, 'Twas Passing Strange; 'Twas Pitiful, 'Twas Wondrous Pitiful," 1986 SUP. CT. REv. 1.

8. Sullivan, supra note 3, at 126 . The opinion was 44 Liquormart, Inc. 
speech ... ?"' In this Nimmer Lecture, the last of the twentieth century, I propose to pursue the two inquiries posed by Van Alstyne.

In Part I of this Lecture, I discuss how the constitutional category of "commercial speech" might be defined for purposes of the First Amendment. A definition of the category should explain, first, how commercial speech differs from forms of expression that receive "core" ${ }^{\text {"10 }}$ First Amendment protections. And it should explain, second, how the category of commercial speech ought to be distinguished from the innumerable kinds of commercial communications, ranging from professional speech to product safety warnings, that do not receive the First Amendment protections even of "commercial speech."

I argue, that core First Amendment protections extend to those forms of communication that are deemed necessary to ensure that a democratic state remains responsive to the views of its citizens. "The Court has called these forms of communication "public discourse," with constitutional value because they are regarded as constituting participation in the process of democratic self-governance. Commercial speech, by contrast, consists of communication about commercial matters that conveys information necessary for public decision making, but that does not itself form part of public discourse. Commercial speech differs from public discourse because it is constitutionally valued merely for the information it disseminates, rather than for being itself a valuable way of participating in democratic self-determination.

Commercial speech doctrine protects only certain kinds of commercial communications that disseminate information, however, and I argue that these are communications distributed through an impersonal public communicative sphere in which persons are understood to be independent and rational. Commercial communications that do not receive the First Amendment protections of commercial speech doctrine, by contrast, typically occur in social settings that are personal, or that involve persons who are deemed dependent, vulnerable, or not fully rational.

9. William Van Alstyne, Essay, Remembering Melville Nimmer: Some Cautionary Notes on Commercial Speech, 43 UCLA L. REV. 1635, 1637 (1996) (footnote omitted).

10. See Frederick Schauer, Commercial Speech and the Architecture of the First Amendment, $56 \mathrm{U}$. CIN. L. Rev. 1181, 1185 (1988). On the First Amendment contrast between "core" and "periphery," see David F. McGowan, A.Critical Analysis of Commercial Speech, 78 CAL. L. REV. 359, 430-36 (1990).

11. See Robert C. Post, Between Democracy and Community: The Legal Constitution of Social Form, in NOMOS XXXV: DEMOCRATIC COMMUNITY 163 (John W. Chapman \& lan Shapiro eds., 1993).

12. See, e.g., Rosenberger v. Univ. of Va., 515 U.S. 819, 831 (1995); Hustler Magazine, lnc. v. Falwell, 485 U.S. 46, 55 (1988). 
In Part II of this Lecture, 1 argue that the particular constitutional values defining commercial speech illuminate many of the doctrinal rules that apply to it. Ironically, the "subordinate" status of commercial speech is a consequence of the fact that commercial speech doctrine expresses the theory, first articulated by Alexander Meiklejohn, that the constitutional function of communication is to inform an audience of citizens about matters pertinent to democratic decision making. First Amendment protections of public discourse, by contrast, tend to focus on safeguarding the capacity of speakers to participate in the process of self-governance. This contrast between a Meiklejohnian account of self-determination and what might be called a participatory theory of self-governance ${ }^{13}$ illuminates why commercial speech doctrine does not prohibit compelled speech, overbroad government regulations, or prior restraints.

The fundamental flaw in contemporary commercial speech doctrine, however, is that its primary doctrinal standard, the so-called Central Hudson test, ${ }^{14}$ is so vague and abstract as to fail entirely to express any specific constitutional values. Allegiance to the formal terms of the Central Hudson test has masked growing differences within the Court about the rationale and purpose of commercial speech doctrine. In recent years these differences have grown so sharp that they threaten the very coherence of the doctrine. I conclude this Lecture by assessing these differences and suggesting possible reformulations of the Central Hudson test that might enable it more accurately to reflect the theoretical justifications of commercial speech doctrine.

\section{Defining COMmercial SPEeCH}

Commercial advertising comprises the core of the constitutional category of "commercial speech." But sometimes advertising is deemed to be public discourse rather than commercial speech ${ }^{15}$ and sometimes expression that would not ordinarily be regarded as advertising is included within the category of commercial speech. ${ }^{16}$ The boundaries of the category are thus quite blurred.

It might be thought that we could sharpen our apprehension of the category by identifying particular characteristics uniquely shared by all communicative acts within it. But efforts to pursue this line of analysis have proved

13. On the distinction between Meiklejohnian and participatory theories of democratic self-government, see ROBERT C. POST, CONSTITUTIONAL DOMAINS: DEMOCRACY, COMMUNITY, MANAGEMENT 268-89 (1995). See also Robert Post, Equality and Autonomy in First Amendment Jurisprudence, $95 \mathrm{MICH}$. L. REV. 1517 (1997) (addressing theories of self-government).

14. See Cent. Hudson Gas \& Elec. Corp. v. Pub. Serv. Comm'n, 447 U.S. 557, 566 (1980). For a full statement of the test, see infra text accompanying note 155 .

15. See, e.g., N.Y. Times Co. v. Sullivan, 376 U.S. 254, 265-66 (1964).

16. See, e.g., Bolger v. Youngs Drug Prods. Corp., 463 U.S. 60 (1983). 
frustrating. Commercial speech cannot be defined by a set of characteristics uniquely shared by its speakers, because no such characteristics can be specified. Although it is true that commercial speakers are typically paid for their speech and that they communicate in order to earn profits, so also do many speakers whose communications receive the "full" protection of the First Amendment earn recompense for their speech and publish for profit. ${ }^{17}$ Although it is true that commercial speakers seek to solicit for the sale of goods, so also do many speakers who engage in fully protected forms of speech. ${ }^{18}$

If we instead seek to define commercial speech by its content, rather than by the attributes of its speakers, we confront the paradox that the classification of any particular communication can sometimes depend entirely upon the identity of its speaker. A pharmacist who advertises drug prices is said to engage in commercial speech, ${ }^{19}$ but the publication of these same prices by Consumer Reports would likely merit full First Amendment protection. ${ }^{20}$ Certainly the pamphlet describing venereal disease and condoms, which the Court deemed commercial speech when distributed by a condom manufacturer, ${ }^{21}$ would receive full protection if published by an AIDS prevention group. ${ }^{22}$

17. See Smith v. California, 361 U.S. 147, 150 (1959) (books); Joseph Burstyn, Inc. v. Wilson, 343 U.S. 495, 501 (1952) (motion pictures).

18. See, e.g., Vill. of Schaumburg v. Citizens for a Better Env't, 444 U.S. 620, 630-32 (1980); Thomas v. Collins, 323 U.S. 516, 531 (1945) (holding that First Amendment protection cannot be denied merely because "an organization for which the rights of free speech ... are claimed is one 'engaged in business activities' or that the individual who leads it in exercising these rights receives compensation for doing so"); Murdock v. Pennsylvania, 3 I9 U.S. 105, 11012.(1943).

19. See Va. State Bd. of Pharmacy v. Va. Citizens Consumer Council, Inc., 425 U.S. 748, 761 ( 1976$)$.

20. See Lowe v. SEC, 472 U.S. 181, 210 n.58 (1985); Daniel A. Farber, Commercial Speech and First Amendment Theory, 74 NW. U. L. REV. 372, 381-83 (1979); Steven Shiffrin, The First Amendment and Economic Regulation: Away From a General Theory of the First Amendment, 78 NW. U. L. REV. 1212, 1257 (1983).

21. See Bolger, 463 U.S. at 67. The eight-page pamphlet discussed "at length the problem of venereal disease and the use and advantages of condoms in aiding the prevention of venereal disease." Id. at 63 n. 4 .

22. Just as it is impossible to specify uniquely the attributes of commercial speech, so it is impossible to specify a set of government purposes that apply only to commercial speech. It is sometimes said, for example, that commercial speech gives rise to a special government interest in suppressing "misleading" communication. Thus Justice John Paul Stevens has written that "any description of commercial speech that is intended to identify the category of speech entitled to less First Amendment protection should relate to the reasons for permitting broader regulation: namely, commercial speech's potential to mislead." Rubin v. Coors Brewing Co., 514 U.S. 476, 494 (1995) (Stevens, J., concurring); see 44 Liquormart, Inc. v. Rhode Island, 517 U.S. 484, 501 (1996) (Stevens, J., plurality opinion) (joined by Kennedy, J. and Ginsburg, J.). But the danger of "misleading" communication exists in fully protected speech as well as in commercial speech. It is certainly as important to regulate misleading political advertisements as it is to police misleading commercial advertisements for eggs. See Nat'l Comm'n on Egg Nutrition v. FTC, 570 F.2d 157, 162-63 (7th Cir. 1977). If the 
The impossibility of uniquely identifying the attributes of commercial speech has been much noted. In 1976, Justice Harry Blackmun asserted that the very obscurity of the category of commercial speech meant that it could not be entirely without First Amendment protection. ${ }^{23}$ In recent times commentators have urged that this same obscurity implies that commercial speech cannot be systematically relegated to a subordinate First Amendment position. ${ }^{24}$ Whatever its implications, the impossibility of specifying the parameters that define the category of commercial speech has haunted its jurisprudence and scholarship.

On close inspection, however, this difficulty may derive from an implicit presumption about what ought to count as a satisfactory definition. We have sought to define the category of commercial speech by searching for unique characteristics possessed by speech acts included within the category. But the issue can be approached from a different angle. We might seek to define the category by reference to the constitutional values it is designed to serve. It is not uncommon for First Amendment categories to be defined in this way.

I have argued elsewhere, for example, that the boundaries of "public discourse" are normatively defined. Public discourse is comprised of those processes of communication that must remain open to the participation of citizens if democratic legitimacy is to be maintained. ${ }^{25}$ The basic idea is that democratic legitimacy depends upon citizens having the warranted belief that their government is responsive to their wishes. Public discourse consists of the various kinds of communicative action to which citizens must have unrestricted access if this belief is to be sustained. Within public discourse citizens forge, in the words of Learned Hand, the "public opinion which is the final source of government in a democratic state. ${ }^{p 26}$ The possibility of participating in the formation of public opinion authorizes citizens to imagine themselves as included within the process of collective self-determination. ${ }^{27}$

First Amendment treats the two forms of regulation differently, as it surely does, see Shiffrin, supra note 20 , at 1231 , it is not because the government interest in ensuring accurate information is any less for political, than for commercial speech. It is rather because commercial speech and political discourse implicate different kinds of constitutional values.

23. See Va. Pharmacy, 425 U.S. at 761-62.

24. See, e.g., Kozinski \& Banner, supra note 3.

25. See, e.g., Robert Post, The Constitutional Concept of Public Discourse: Outrageous Opinion, Democratic Deliberation, and Hustler Magazine v. Falwell, 103 HARV. L. REV. 601 (1990) [hereinafter Post, Constitutional Concept]; Robert Post, Meiklejohn's Mistake: Individual Autonomy and the Reform of Public Discourse, 64 U. COLO. L. REV. 1109 (1993) [hereinafter Post, Meiklejohn's Mistake].

26. Masses Pub. Co. v. Patten, 244 F. 535, 540 (S.D.N.Y.), rev'd, 246 F. 24 (2d Cir. 1917).

27. For an argument that the right to vote is by itself insufficient to maintain this sense of inclusion, see Post, supra note 13, at 1525-28. 
This is what I have called the "participatory" model of democratic selfgovernance.

Just as the participatory model suggests that the definition of the category of public discourse is determined by reference to constitutional values, ${ }^{28}$ so I argue in this Lecture that the category of commercial speech should also be defined by reference to constitutional values. The question, therefore, is what constitutional values the category of commercial speech might be designed to serve.

When he invented the contemporary category of commercial speech in his opinion in Virginia State Board of Pharmacy v. Virginia Citizens Consumer Council, Inc., ${ }^{29}$ Justice Blackmun proposed that the category was necessary to implement two distinct constitutional values.

Advertising ... is nonetheless dissemination of information as to who is producing and selling what product, for what reason, and at what price. So long as we preserve a predominantly free enterprise economy, the allocation of our resources in large measure will be made through numerous private economic decisions. It is a matter of public interest that those decisions, in the aggregate, be intelligent and well informed. To this end, the free flow of commercial information is indispensable.... And if it is indispensable to the proper allocation of resources in a free enterprise system, it is also indispensable to the formation of intelligent opinions as to how that system ought to be regulated or altered. Therefore, even if the First Amendment were thought to be primarily an instrument to enlighten public decisionmaking in a democracy, we could not say that the free flow of information does not serve that goal. ${ }^{30}$

Justice Blackmun's first suggestion is that commercial speech ought to be constitutionally protected in order to ensure "the proper allocation of resources in a free enterprise system." Generalizing from the needs of consumers who might urgently require information about drug prices, Blackmun in Virginia Pharmacy concludes that "society also may have a strong interest in the free flow of commercial information." ${ }^{31}$ He argues, in effect, that "the efficient allocation of resources depends upon informed consumer choices, ${ }^{, 32}$ which in turn

28. For a full discussion, see Post, Constitutional Concept, supra note 25 , at 667-84.

29. 425 U.S. 748 (1976).

30. Id. at 765 .

31. Id. at 763-64.

32. Friedman v. Rogers, 440 U.S. 1, 9 (1979). 
requires the free circulation of commercial information. Later cases have specifically reaffirmed this reasoning. ${ }^{33}$

Although economic efficiency is no doubt an important consideration for government policy, it is difficult to see why it should be a specifically First Amendment concern. As Steven Shiffrin pointedly asks, "Why should allocation of resources be a First Amendment worry?"? The First Amendment does not require courts to scrutinize government actions that directly interfere with the efficiency of the market, as for example by setting prices or prohibiting products. Why then should the First Amendment be concerned with the more indirect effects of advertising regulations on market efficiency?

A tempting response to this question is that advertising is a form of communication, and the First Amendment is always triggered when the government regulates "speech as such." 35 There are, however, three reasons why this temptation ought to be firmly resisted. The first is that it is probably false to say that the First Amendment is triggered whenever government regulates "speech as such." ${ }^{36}$ I have elsewhere argued this point at length, ${ }^{37}$ but suffice it to say that social life is full of communicative processes that are routinely regulated without the benefit of First Amendment analysis. The process of contract formation, for example, consists entirely of communication, but its regulation does not trigger First Amendment scrutiny. Such scrutiny is brought to bear only when the regulation of communication affects a constitutional value specifically protected by the First Amendment.

Second, even if "speech as such" were to trigger some form of First Amendment protection, we would not know the nature of that protection until we could assess the constitutional values potentially imperiled by government

33. In his opinion for the Court in Rubin v. Coors Brewing Co., 514 U.S. 476, 481-82 (1995), for example, Justice Clarence Thomas cites economic efficiency as the reason why the First Amendment protects commercial speech:

Though we once took the position that the First Amendment does not protect commercial speech, we repudiated that position in Virginia Board of Pharmacy v. Virginia Citizens Consumer Council, Inc. There we noted that the free flow of commercial information is "indispensable to the proper allocation of resources in a free enterprise system" because it informs the numerous private decisions that drive the system. Indeed, we observed that a "particular consumer's interest in the free flow of commercial information ... may be as keen, if not keener by far, than his interest in the day's most urgent political debate."

Id. (citations omitted) (quoting Va. Pharmacy, 425 U.S. at 763, 765).

34. STEVEN H. SHIFFrIN, DisSENT, INJUSTICE, AND THE MEANINGS OF AMERICA 40 (1999).

35. Glickman v. Wileman Bros. \& Elliott, Inc., 521 U.S. 457, 478 (1997) (Souter, J., dissenting); see Smolla, supra note 3, at 780 .

36. Frederick Schauer demonstrated this point almost two decades ago. See Frederick Schauer, Categories and the First Amendment: A Play in Three Acts, 34 VAND. L. REV. 265, 268-71 (1981).

37. See Robert Post, Recuperating First Amendment Doctrine, 47 STAN. L. REV. 1249, 1254-55 (1995). 
regulation. First Amendment protections vary depending upon the constitutional significance of the speech that the government seeks to regulate, ${ }^{38}$ and this significance is measured by the constitutional values that we understand the First Amendment to serve. Whatever constitutional values we attribute to the First Amendment, however, will necessarily distinguish between communicative acts that are pertinent to their fulfillment and those that are not. ${ }^{39}$ This is true even of the most general kinds of First Amendment values, like autonomy or self-realization. ${ }^{40}$ It is not clear, then, what it would even mean to claim that "speech as such" is constitutionally protected, because as soon as one specifies the constitutional values necessary to give shape and substance to that protection, particular communicative acts that do not serve these values will be excluded.

Third, even if "speech as such" were to merit some form of First Amendment protection, there is no reason whatsoever to believe that the constitutional value by which such protection should be measured is that of efficiently allocating resources in a free-market society. To locate such a value in the First Amendment would be to justify Chief Justice William Rehnquist's charge that the jurisprudence of commercial speech is really a revival of "the discredited doctrine" of substantive due process "of cases such as Lochner $v$. New York and Tyson $\mathcal{E}$ Brother v. Banton." ${ }^{, 41}$ The First Amendment cannot be understood as a repository of microeconomic theory, as the champion of a particular (and contested) view of proper market functioning. To the contrary, the First Amendment creates the very space in which all potential theories of marketplace functioning can be debated and evaluated. Nothing could be more damaging to the First Amendment than to equate it with a specific economic perspective, and in this way to transform it into a mere "basis for reviewing economic regulations." ${ }^{42}$

For these reasons, commercial speech doctrine should not be defended on the ground that commercial advertising serves the First Amendment value of market efficiency. We must turn, then, to the second constitutional principle that Blackmun articulates in Virginia Pharmacy. This principle

38. See POST, supra note 13 , at 16-17; infra notes $217-221$ and accompanying text.

39. See Post, supra note 37, at 1271-73. So, for example, if the constitutional value of speech is thought to lie in its "truth-seeking function," Hustler Magazine, lnc. v. Falwell, 485 U.S. 46,52 (1988), then the Constitution will protect only those speech acts that facilitate this function.

40. See Baker, supra note 2; Post, supra note 37, at 1272-73.

41. Cent. Hudson Gas \& Elec. Corp. v. Pub. Serv. Comm'n, 447 U.S. 557, 591 (1980) (Rehnquist, J., dissenting); see id. at 589; Jackson \& Jeffries, supra note 2, at 25-33; Cass R. Sunstein, Lochner's Legacy, 87 COLUM. L. REV. 873, 883-84 (1987); David Yassky, Eras of the First Amendment, 91 CoLUM. L. REV. 1699, 1737 (1991).

42. Glickman v. Wileman Bros. \& Elliott, Inc., 521 U.S. 457, 476 (1997). 
concerns the enlightenment of "public decisionmaking in a democracy.", Blackmun contends that commercial speech facilitates a "free flow of commercial information" that "may be of general public interest." According to this approach, commercial speech should receive constitutional protection in order to safeguard "the essential role that the free flow of information plays in a democratic society. ${ }^{15}$

Underlying this approach is the notion that citizens may acquire information from commercial speech that is highly relevant to the formation of democratic public opinion. Democratic public opinion, in turn, is the ultimate source of government decision making. If citizens learn from commercial advertising that pharmacy drugs are too expensive, for example, they might organize politically to advocate within public discourse for the creation of national health insurance. If they learn from commercial advertising that the cost of gasoline is on the rise, they might organize politically to advocate within public discourse for government price controls.

Commercial speech might also be relevant to the formation of public opinion in a second and ultimately more profound sense. Although public discourse includes specific debates about potential policy decisions, it is also an arena suffused with intense and contentious articulations of collective identity. ${ }^{46}$ Within public discourse, heterogeneous and conflicting visions of national identity continuously collide and reconcile. These visions may or may not have immediate policy implications, but they are nevertheless highly significant for the general orientation of the nation. Visions of the good life articulated within commercial advertisements are relevant to this process. Any observer of the American scene would report that advertising deeply influences our sense of ourselves as a nation. ${ }^{47}$ The canonical photographs of Walker Evans, for example, poignantly chronicle the significance of

43. Va. State Bd. of Pharmacy v. Va. Consumer Council, Inc., 425 U.S. 748, 765 (1976).

44. Id. at 764 .

45. 44 Liquormart, 1nc. v. Rhode Island, 517 U.S. 484, 512 (1996) (Stevens, J., plurality opinion) (joined by Kennedy, J., Thomas, J., and Ginsburg, J.). The year after Virginia Pharmacy, Justice Harry Blackmun again referred to the two distinct constitutional justifications for commercial speech doctrine, but with a slightly different emphasis:

The listener's interest is substantial: the consumer's concern for the free flow of commercial speech often may be far keener than his concern for urgent political dialogue. Moreover, significant societal interests are served by such speech. Advertising, though entirely commercial, may often carty information of import to significant issues of the day. And commercial speech serves to inform the public of the availability, nature, and prices of products and services, and thus performs an indispensable role in the allocation of resources in a free enterprise system.

Bates v. State Bar of Ariz., 433 U.S. 350, 364 (1977) (citation omitted).

46. See Post, Meiklejohn's Mistake, supra note 25, at 1116-19.

47. See, e.g., Stuart Ewen, Advertising and the Development of Consumer Society, in CULTURAL POLITICS IN CONTEMPORARY AMERICA 82 (lan Angus \& Sut Jhally eds., 1989). 
commercial advertisements as embodiments of personal and national ideals. ${ }^{48}$ This kind of influence is probably as important to the formation of democratic public opinion, and hence to public decision making, as the discrete price information at stake in Virginia Pharmacy.

This explanation of the constitutional value of commercial speech resonates with traditional First Amendment reasoning. ${ }^{49}$ Almost from the outset of its First Amendment jurisprudence, the Court has viewed freedom of speech as serving the purpose of democratic self-government. ${ }^{50}$ There are, however, competing theories about how this purpose should be understood.

One theory, which has deeply informed the development of First Amendment jurisprudence, is the participatory model, the outlines of which 1 have already sketched. The participatory model emphasizes the importance of preserving uncensored access to public discourse so that citizens can maintain the warranted sense that their government is responsive to them. ${ }^{51}$ The participatory model protects public discourse in order to preserve a necessary (but not sufficient) precondition for democratic legitimation. Commercial speech, however, does not seem a likely candidate for inclusion within public discourse, because we most naturally understand persons who are advertising products for sale as seeking to advance their commercial interests rather than as participating in the public life of the nation. We do not characterize them as inviting reciprocal dialogue or discussion; nor do we perceive their speech as an effort to make the state responsive to them. We instead view them as attempting to sell products. If pressed, this is not ultimately a judgment about the motivations of particular persons, but instead about the social significance of a certain kind of speech. ${ }^{52}$

48. The recent Walker Evans exhibition at the Metropolitan Museum of Art in New York, for example, illustrates the extent to which Evans was seized by manifold ways in which the utopian aspirations of mass marketing images affected the perspectives of his subjects, particularly amid the harsh realities of the Depression. See WALKER EVANS (compiled by Metro. Museum of Art, N.Y., 2000).

49. "[T]he Court recognized that commercial advertising indirectly contributes to the ends traditionally served by the $[\mathrm{F}]$ irst $[\mathrm{A}]$ mendment by supplying the public with information, images, and values that may enter into the discussion of public issues..." Thomas W. Merrill, Comment, First Amendment Protection for Commercial Advertising: The New Constitutional Doctrine, 44 U. CHI. L. REV. 205, 226-27 (1976).

50. In one of its earliest opinions, for example, the Court reasoned that "The maintenance of the opportunity for free political discussion to the end that government may be responsive to the will of the people and that changes may be obtained by lawful means ... is a fundamental principle of our constitutional system." Stromberg v. California, 283 U.S. 359, 369 (1931).

51. For a brief explanation of the participatory model, see supra notes 25-27 and accompanying text.

52. It is not uncommon for First Amendment jurisprudence to employ categorical judgments in this way, to decide what kinds of communicative acts will be included or excluded from public discourse. A similar categorical judgment is visible, for example, in the Court's effort to distinguish public discourse from obscenity: "The protection given speech and press was fashioned to assure 
It remains true, however, that commercial speech affects public discourse. The impact of commercial speech on the formation of public opinion may be conceived as a by-product of the effort to sell goods. To capture this insight, Blackmun appeals in Virginia Pharmacy to a theory of democratic self-governance that is quite different from the participatory model. Blackmun summons instead the account of Alexander Meiklejohn.

Meiklejohn famously argued that "the final aim" of First Amendment freedom is to ensure the circulation of opinion and information necessary for "the voting of wise decisions. ${ }^{.53}$ Meiklejohn believed that constitutional protections should be focused on the rights of citizens to receive information, rather than on the rights of speakers to express themselves. That is why he concluded that "[w]hat is essential is not that everyone shall speak, but that everything worth saying shall be said. ${ }^{.54}$ In the succinct words of a modern Meiklejohnian: "We allow people to speak so others can vote. Speech allows people to vote intelligently and freely, aware of all the options and in possession of all the relevant information." 55 Meiklejohn's influence is perceptible in various areas of First Amendment doctrine, most notably in the regulation of broadcast media, in which the Court has held that "[i]t is the right of the viewers and listeners, not the right of the broadcasters, which is paramount." ${ }^{150}$

unfettered interchange of ideas for the bringing about of political and social changes desired by the people.' But the public portrayal of hard-core sexual conduct for its own sake, and for the ensuing commercial gain, is a different matter." Miller v. California, 413 U.S. 15, 34-35 (1973) (citation omitted) (quoting Roth v. United States, 354 U.S. 476, 484 (1957)). For other examples, see Post, Constitutional Concept, supra note 25, at 676-77. Such categorical judgments are the means by which constitutional law distinguishes and evaluates discrete social practices. For examples, see Post, supra note 37, at 1274-75, and infra text accompanying notes 63-69.

53. AleXANDER Meiklejohn, POlitical FreEDOM: The CONSTitutional POWERS OF THE PEOPLE 26 (1960).

54. Id.

55. OWen M. FISS, LIBERALISM DiVIDED: FREEDOM OF SPEECH AND THE MANY USES OF STATE POWER 13 (1996). Of course it is somewhat ironic to attribute protection for commercial speech to a Meiklejohnian analysis, because it was Alexander Meiklejohn himself who remarked that "[t]he constitutional status of a merchant advertising his wares ... is utterly different from that of a citizen who is planning for the general welfare." MEIKLEJOHN, supra note 53, at 37. See Halberstam, supra note 6, at 805-15; Redish, supra note 3, at 434-38. Meiklejohn took the town meeting as the essential model for protected speech, and he thus might well have assumed that constitutional safeguards extended only to those who, unlike merchants advertising their wares, meant to participate in the public dialogue of the town meeting. But his sharp focus on the constitutional importance of the flow of information to voters is in tension with this assumption, and there is certainly a plausible Meiklejohnian logic to the position that information about commercial prices and products is necessary in order to inform democratic decision making.

56. Red Lion Broad. Co. v. FCC, 395 U.S. 367, 390 (1969). For a discussion, see Robert C. Post, Subsidized Speech, 106 YALE L.J. 151, 158-61 (1996). The speech of broadcasters is regulated in ways that would be plainly unconstitutional if applied to participants in public discourse. See, e.g., FCC v. Nat'l Citizens Comm'n for Broad., 436 U.S. 775, 800 (1978); Miami Herald Publ'g Co. v. Tornillo, 418 U.S. 241 (1974). The difference lies in the fact that broadcasters, 
The Court's development of commercial speech doctrine closely tracks Meiklejohn's analysis. The Court has been quite explicit that commercial speech should be constitutionally protected so as to safeguard the circulation of information. It has therefore focused its analysis on the need to receive information, rather than on the rights of speakers. Two years after Virginia Pharmacy, for example, the Court declared that

the First Amendment goes beyond protection of ... the selfexpression of individuals to prohibit government from limiting the stock of information from which members of the public may draw. A commercial advertisement is constitutionally protected not so much because it pertains to the seller's business as because it furthers the societal interest in the "free flow of commercial information.".57

And in the authoritative case of Central Hudson Gas $\mathscr{E}$ Electric Corp. v. Public Services Commission, ${ }^{58}$ the Court flatly pronounced that "[t]he First Amendment's concern for commercial speech is based on the informational function of advertising., 59

This focus on information introduces an important point of difference from the First Amendment protections that apply to public discourse. It is a necessary condition for democratic legitimacy that citizens have free access to public discourse, because censoring a citizen's ability to contribute to public opinion renders the government, with respect to that citizen, "heteronomous and nondemocratic."160 Many of the First Amendment safeguards of public discourse therefore are speaker oriented. ${ }^{61}$ Commercial speech doctrine, by contrast, is sharply audience oriented. From a constitutional point of view, the censorship of commercial speech does not endanger the process of democratic legitimation. It does not threaten to alienate citizens from their govern-

unlike newspapers, are in some respects constitutionally regarded as public trustees for the interests of the public, rather than as independent participants in public discourse. See, e.g., Red Lion Broad. Co., 395 U.S. at 389-90.

57. First Nat'l Bank v. Bellotti, 435 U.S. 765, 783 (1978) (quoting Va. State Bd. of Pharmacy v. Va. Consumer Council, lnc., 425 U.S. 748, 764 (1976)).

58. 447 U.S. 557 (1980).

59. Id. at 563; see Farber, supra note 20, at 384.

60. Robert C. Post, Racist Speech, Democracy, and the First Amendment, 32 WM. \& MARY L. REV. 267, 290 (1991). For a full discussion, see id. at 279-85.

61. See Post, supra note 13, at 1526-28. I do not mean to imply, of course, that ordinary First Amendment protections do not also extend to audiences. For one thing, the participatory model of democratic self-governance seeks to preserve the potential for the kinds of speaker-audience relationships that constitute our concept of "participation." See Bd. of Educ. v. Pico, 457 U.S. 853, 867 (1982) (Brennan, J.); Martin v. Ciry of Struthers, 319 U.S. 141, 143 (1943). For another, the participatory model stresses the importance of collective self-determination, which requires constitutional protection for the dialogue and exchange of information within which that selfdetermination can responsibly proceed. See POST, supra note 13, at 272-76. These protections must extend to both speakers and audience. 
ment or to render the state heteronomous with respect to speakers. Instead it merely jeopardizes the circulation of information relevant to "the voting of wise decisions." ${ }^{62}$

We may thus construct a rough and incomplete definition of commercial speech as the set of communicative acts about commercial subjects that conveys information of relevance to democratic decision making, but that does not itself form part of public discourse. There are, however, two difficulties with this definition. The first is that it does not explain how speech can provide information of relevance to public decision making and yet not be part of public discourse. The second is that the definition is vastly overinclusive, because there are numerous forms of speech about commercial subjects that contain information relevant to democratic decision making and yet that do not receive even the weak protection afforded to commercial speech.

To understand the definition I have proposed, therefore, it is necessary to explore carefully two distinctions that are implicit within it. The first concerns the difference between commercial speech and public discourse; the second concerns the difference between commercial speech and the many communicative acts about commercial subjects that are not included within the First Amendment protections of commercial speech doctrine.

\section{A. The Distinction Between Commercial Speech and Public Discourse}

It is useful to investigate how the Court constructs the boundary between public discourse and commercial speech in the context of specific cases. Consider, for example, Murdock $v$. Pennsylwania, ${ }^{63}$ in which the Court had before it a city ordinance requiring that "all persons . . . soliciting . . . orders for goods ... or merchandise of any kind" purchase a license. ${ }^{64}$ The Court found it unconstitutional to apply this ordinance to Jehovah's Witnesses engaged in "door to door" solicitation for the purchase of "certain religious books and pamphlets."

The alleged justification for the exaction of this license tax is the fact that the religious literature is distributed with a solicitation of funds.... Situations will arise where it will be difficult to determine whether a particular activity is religious or purely commercial. . . As we stated only the other day, in Jamison v. Texas, "The states can

62. MEIKLEJOHN, supra note 53, at 26; see Halberstam, supra note 6, at 831-32; Burt Neuborne, A Rationale for Protecting and Regulating Commercial Speech, 46 BROOK. L. REV. 437 , 454 (1980). I should stress that the "information" disseminated by commercial speech includes the visions of collective identity powerfully present in advertising.

63. 319 U.S. 105 (1943).

64. Id. at 106 .

65. Id. 
prohibit the use of the streets for the distribution of purely commercial leaflets, even though such leaflets may have 'a civic appeal, or a moral platitude' appended. ... They may not prohibit the distribution of handbills in the pursuit of a clearly religious activity merely because the handbills invite the purchase of books for the improved understanding of the religion or because the handbills seek in a lawful fashion to promote the raising of funds for religious purposes." But the mere fact that the religious literature is "sold" by itinerant preachers rather than "donated" does not transform evangelism into a commercial enterprise... The constitutional rights of those spreading their religious beliefs through the spoken and printed word are not to be gauged by standards governing retailers or wholesalers of books. The right to use the press for expressing one's views is not to be measured by the protection afforded commercial handbills.... It is plain that a religious organization needs funds to remain a going concern.... [T] he problem of drawing the line between a purely commercial activity and a religious one will at times be difficult. On this record it plainly cannot be said that petitioners were engaged in a commercial rather than a religious venture. ${ }^{66}$

The passage repays close reading. The Court poses the question of whether the Jehovah's Witnesses "were engaged in a commercial rather than a religious venture." This question does not focus on the narrow communicative act of selling a Bible, but rather on the larger "venture" or "activity" within which the particular communicative act is embedded. Constitutional characterization of the act of solicitation depends upon its context, for the Court is explicit that hawking a Bible would present a different constitutional issue if it merely involved the "venture" of retailing commercial goods. ${ }^{67}$

Murdock therefore turns on a judgment about what may be called the social practice of religion. Essential to the case is an evaluation of what it means to be a Jehovah's Witness, as distinct from a retailer of goods. The Court concludes that the attempts of the Jehovah's Witnesses to sell religious books should be understood as part of their efforts to support and spread "their religious beliefs."

66. Id. at 110-11 (citations omitted) (quoting Jamison v. Texas, 318 U.S. 413, 417 (1943)).

67. Actually, the Court refers to the venture of retailing or wholesaling books. I have varied the reference in text because a modern understanding of commercial speech doctrine might well exclude advertisements for "activity that itself is protected by the lF]irst [A Imendment." Merrill, supra note 49 , at 235 .

68. Murdock, 319 U.S. at 1I7. One can only imagine what kind of a conclusion the Court would reach were it confronted with the case of a scientologist selling Dianetics by L. Ron Hubbard. Would the scientologist be cast as a religious speaker? as a political disputant? as a merely commercial salesman? The divide between commercial and political speech is constructed through judgments like these, which involve the characterization of social practices. 
The conclusion that the solicitations of the Jehovah's Witnesses should legally be regarded as inseparable from their engagement in religious "evangelism" exemplifies the way in which constitutional law presupposes active judicial characterization of the social world. The conclusion requires the Court to address the question of whether evangelism should be understood as a protected effort to shape public opinion. Because the Court is clear that religious dialogue is "essential to enlightened opinion and right conduct on the part of the citizens of a democracy, ${ }^{, 69}$ it holds that the solicitations of the Jehovah's Witnesses should receive full constitutional protection.

The logic that underlies Murdock is thus complex and subtle. It requires the Court to determine, first, the place of the Jehovah's Witnesses' solicitations within the venture of religious evangelism, and, second, the place of such evangelism within the creation of the public opinion necessary for democratic self-governance. Both these judgments are thoroughly evaluative, because both ultimately turn on charting and classifying the social world in order best to serve the constitutional value of democratic self-determination.

This kind of analysis is typical in decisions in which the Court has attempted to distinguish commercial speech from public discourse. Take, for example, a case like Thomas v. Collins, ${ }^{70}$ in which the Court had to decide whether a Texas statute requiring labor organizers to register with the state "before soliciting any members for" their organizations was to be construed as a restraint on public discourse or instead as a simple regulation of "business practice," "like selling insurance, dealing in securities, acting as commission merchant, pawnbroking, etc." "3

The Court observed that

it does not resolve where the line shall be drawn... merely to urge ... that an organization for which the rights of free speech and free assembly are claimed is one "engaged in business activities" or that the individual who leads it in exercising these rights receives compensation for doing so. These comparisons are at once too simple, too general, and too inaccurate to be determinative. Where the line shall be placed in a particular application rests, not on such generalities, but on the concrete clash of particular interests and the community's relative evaluation both of them and of how the one will be affected by the specific restriction, the other by its absence. ${ }^{74}$

69. Cantwell v. Connecticut, 310 U.S. 296, 310 (1940).

70. 323 U.S. $516(1945)$.

71. Id. at 519 n.1.

72. Id. at 527 .

73. Id. at 526 .

74. Id. at 531 . 
The Court explicitly concludes that no simple fact, like the presence of a business interest or compensation, can distinguish commercial from political speech. Particular facts are of course relevant, but, viewed in isolation, not determinative. What is determinative is the achievement of constitutional purposes. Normative judgments of this kind, as the sociologist Philip Selznick observes, always require "contextual thinking," ${ }^{75}$ a close attention to "textured meanings and concrete understandings." ${ }^{, 76}$

Selznick's observation explains why the contemporary Court has in its commercial speech doctrine persistently gestured toward "the 'commonsense' distinction" ment's core." The evaluations of "commonsense". are complex, contextual, and ultimately inarticulate; the Court's appeal to common sense acknowledges that the achievement of constitutional purposes cannot be reduced to any simple rule or determinate criteria. The judgments of common sense ultimately revolve around questions of social meaning; they turn on whether the utterance of a particular speaker should be understood as an effort to engage public opinion or instead simply to sell products. The Court is thus quite misleading occasionally to assert that commercial speech can be distinguished from public discourse merely on the basis of its content, as though commercial speech were any communication "that does no more than propose a commercial transaction," ${ }^{79}$ or any "expression related solely to the economic interests of the speaker and its audience. ${ }^{, 80}$

Murdock and Thomas suggest that the distinction between commercial speech and public discourse turns very much on precisely what it means to relate "solely" to economic interests, or to do "no more" than propose a transaction. These phrases must be understood to reflect judgments about "the character of the expressive activity" at issue, ${ }^{81}$ judgments that necessarily entail an assessment of the nature and constitutional significance of the larger social practice within which that activity is embedded. ${ }^{82}$ That is why com-

75. Philip Selznick, Foundations of Communitarian Liberalism, RESPONSIVE COMMUNITY, Fall 1994, at 16, 21.

76. PHILIP SElzNICK, THE MORAl COMMONWEALTH: SOCIAL THEORY AND THE PROMISE OF COMMUNITY 323 (1992).

77. Rubin v. Coors Brewing Co., 514 U.S. 476, 482 (1995).

78. Fla. Bar v. Went For 1t, 1nc., 515 U.S. 618, 623 (1995).

79. United States v. Edge Broad. Co., 509 U.S. 418, 426 (1993); see also Bd. of Trs. v. Fox, 492 U.S. 469, 482 (1989); Va. State Bd. of Pharmacy v. Va. Consumer Council, Inc., 425 U.S. 748,771 n. 24 (1976).

80. Cent. Hudson Gas \& Elec. Corp. v. Pub. Serv. Comm'n, 447 U.S. 557, 561 (1980).

81. In re Primus, 436 U.S. 412,438 n. 32 (1978).

82. In Primus, for example, the Court held that the solicitation of a public interest American Civil Liberties Union (ACLU) lawyer should be regarded as public discourse. This conclusion rested on a categorical judgment that there was "no basis for equating the work of lawyers associated 
mercial speech cannot be transformed into public discourse merely by altering its content to insert assertions about matters of public concern.

In Thomas, the Court concluded that the solicitation of union members should not be regarded as a narrowly commercial communication. Just as in Murdock the Court had viewed the solicitation of Jehovah's Witnesses as constitutionally inseparable from the practice of religious evangelism, so in Thomas the Court characterized the labor organizer's solicitation as inseparable from the efforts of union labor to participate in the formation of public opinion. ${ }^{84}$ And the Court had no doubt but that such efforts were to be included within public discourse, because " $[\mathrm{f}]$ ree discussion concerning the conditions in industry and the causes of labor disputes appears to us indispensable to the effective

with the ACLU or the NAACP with that of a group that exists for the primary purpose of financial gain through the recovery of counsel fees." Id. at 431. In the Court's view, "Itlhe ACLU engages in litigation as a vehicle for effective political expression and association," id., and public discourse includes "the opportunity to persuade to action, not merely to describe facts." Id. at 432 (quoting Thomas v. Collins, 323 U.S. 516, 537 (1945)).

83. See, e.g., Cent. Hudson, 447 U.S. at 563 n.5. The point is nicely illustrated by the facts of Valentine v. Chrestensen, 316 U.S. 52 (1942), in which the city of New York enforced an ordinance forbidding "distribution in the streets of commercial and business advertising matter" against a businessman who sought to disseminate "a handbill advertising" a submarine "and soliciting visitors for a stated admission fee." Id. at 53 . The businessman cleverly responded by a creating "double-faced handbill." Id.

On one side was a revision of the original, altered by the removal of the statement as to admission fee but consisting only of commercial advertising. On the other side was a protest against the action of the City Dock Department in refusing the respondent wharfage facilities at a city pier for the exhibition of his submarine, but no commercial advertising. The Police Department advised that distribution of a bill containing only the protest would not ... be restrained, but that distribution of the double-faced bill was prohibited.

Id. The businessman, in other words, sought to transform commercial speech into public discourse by inserting words of political protest. When he was restrained by the police, he asserted that "he was engaged in the dissemination of matter proper for public information, none the less so because there was inextricably attached to the medium of such dissemination commercial advertising matter." Id. at 55. The Court, however, would have none of it:

We need not indulge nice appraisal based upon subtle distinctions in the present instance nor assume possible cases not now presented. It is enough for the present purpose that the stipulated facts justify the conclusion that the affixing of the protest against official conduct to the advertising circular was with the intent, and for the purpose, of evading the prohibition of the ordinance. If that evasion were successful, every merchant who desires to broadcast advertising leaflets in the streets need only append a civic appeal, or a moral platitude, to achieve immunity from the law's command.

Id. It is clear, therefore, that Valentine holds that the category of commercial speech does not turn merely on the specific content of particular words, but instead on a constitutional appraisal of "the character of the expressive activity" at issue. Primus, 436 U.S. at 438 n.32. The content of words are relevant to this appraisal, but not determinative.

84. "This case falls in the category of a public speech, rather than that of practicing a vocation as solicitor." Thomas, 323 U.S. at 548 (Jackson, J., concurring). 
and intelligent use of the processes of popular government to shape the destiny of modern industrial society. ${ }^{85}$

Thomas thus displays the same analytic structure as Murdock. The Court seeks, first, to ascertain the "character of the expressive activity" within which a particular speech act is embedded, and then, second, to determine whether that activity is to be included within public discourse. ${ }^{86}$ To include speech within public discourse is to signify that it is constitutionally valued not merely for the contribution it may make to public discussion, but also, intrinsically, for the engagement it represents in the public life of the nation. A democracy cannot flourish unless its citizens actively participate in the formation of its public opinion. Such participation is "precious" ${ }^{87}$ and to be encouraged for its own sake.

This perspective suggests a concise formulation of the First Amendment difference between commercial speech and public discourse. The distinction turns on whether constitutional value attaches to participation in a given speech act, or whether constitutional value attaches instead only to the information conveyed by the speech act.

\section{B. The Distinction Between Commercial Speech and Commercial Communications}

The Court is fond of observing that "[o]ur jurisprudence has emphasized that 'commercial speech [enjoys] a limited measure of protection, commensurate with its subordinate position in the scale of First Amendment values,' and is subject to 'modes of regulation that might be impermissible in the realm of noncommercial expression." ${ }^{88}$ But this observation is highly misleading, for it falsely implies that commercial speech receives less protection than all other forms of expression. Although the First Amendment protections extended to commercial speech are fewer and weaker than those extended to public discourse, commercial speech in fact receives far greater constitutional protection than many forms of commercial communication.

It has rightly been observed that there is a "universe of communication relating only to business activity, having no explicit political or artistic or ideo-

85. Id. at 532 (quoting Thornhill v. Alabama, 310 U.S. 88, 102-03 (1940)).

86. The Court's recent line of cases holding that charitable solicitations are part of public discourse rather than commercial speech displays analogous reasoning. See, e.g., Vill. of Schaumburg v. Citizens for a Better Env't, 444 U.S. 620, 632 (1980).

87. Forsyth County v. Nationalist Movement, 505 U.S. 123, 131 (1992); see also United States v. Robel, 389 U.S. 258, 265 (1967).

88. Bd. of Trs. v. Fox, 492 U.S. 469, 477 (1989) (second alteration in original) (quoting Ohralik v. Ohio State Bar Ass'n, 436 U.S. 447, 456 (1978)); see, e.g., Fla. Bar v. Went For lt, Inc., 515 U.S. $618,623(1995)$. 
logical content, and yet differing substantially from the kind of widespread public hawking of wares represented by the Virginia Pharmacy archetype.. ${ }^{89}$ These include

numerous communications among business executives about prices and business practices now regulated by the Sherman Antitrust Act; representations about products now regulated by various consumer protection laws, by the Uniform Commercial Code, and by the common law of warranty and contract; statements about willingness to enter into a contract now regulated by the common law of contract; and so on and on. ${ }^{90}$

Whatever First Amendment protection the commercial communications within this larger universe are entitled to receive, it is clear that they do not receive the specific constitutional safeguards created by commercial speech doctrine.

Commercial speech doctrine is thus not merely about the boundary that separates commercial speech from public discourse, but also about the boundary that separates the category of "commercial speech" from the surrounding sea of commercial communications that do not benefit from the protections of the doctrine. If the construction of the first boundary must answer to the question of why commercial speech receives less First Amendment protection than public discourse, the construction of the second boundary must answer to the question of why commercial speech doctrine extends special First Amendment protections to some commercial communications but not to others.

Although there are numerous cases in which the Court has more or less explicitly addressed the distinction between commercial speech and public discourse, there are few if any decisions in which the Court has addressed the distinction between the First Amendment category of commercial speech and these other forms of commercial communications. The question is rendered even more confusing by the Court's conclusion that "[f]or commercial speech to come within [the First Amendment], it at least must concern lawful activity and not be misleading."191 $1 \mathrm{t}$ is not clear whether misleading speech is simply "commercial speech" that can be regulated by the state, or whether it is instead excluded even from the category of "commercial speech."

Consideration of the distinction between commercial speech and the general category of commercial communications must thus be at best tentative

89. Schauer, supra note 10 , at 1183 ; see Shiffrin, supra note 20 , at 1213-14.

90. Schauer, supra note 10, at 1184 (footnote omitted).

91. Rubin v. Coors Brewing Co., 514 U.S. 476, 482 (1995) (second alteration in original) (quoting Cent. Hudson Gas \& Elec. Corp. v. Pub. Serv. Comm'n, 447 U.S. 557, 566 (1980)). 
and speculative. In this part, I offer an analytic framework intended to illuminate some of the issues involved in this distinction.

It is often quite useful to begin analysis by focusing on paradigmatic cases. State efforts to prohibit advertisements for drug prices placed by a pharmacist in a local newspaper would unambiguously be analyzed by the First Amendment principles of commercial speech doctrine. An unobtrusive but essential aspect of what makes this case exemplary is the fact that the pharmacist's advertisements are placed in a newspaper. ${ }^{92}$ I have argued elsewhere that newspapers are a medium for the communication of ideas, and that such media constitute the "structural skeleton"193 of a public communicative sphere. Sociologists have defined this sphere as a shared "universe of discourse" ${ }^{194}$ that unites persons who would otherwise be strangers by exposing them "to similar social stimuli." Within the public communicative sphere, persons are presumed to be independent and rational, ${ }^{96}$ and to engage each other through "critical interaction." ${ }^{97}$ The operation of democracy presupposes and requires a public communicative sphere. ${ }^{98}$

A newspaper editorial discussing drug prices would be protected as public discourse, because it would be regarded as an effort to participate in this public communicative sphere in a manner that enacts the constitutional value of democratic self-governance. A pharmacist advertising drug prices in that same newspaper, however, would not be regarded as a participant in public discourse, because her speech would not be deemed to enact the value of democratic self-governance. Nevertheless the pharmacist's advertisement, no less than the newspaper's editorial, would disseminate information to the public at large and in this way serve the important constitutional function of sustaining the public communicative sphere. This is an essential insight of commercial speech doctrine.

We might contrast the pharmacist's advertisement, therefore, with those forms of commercial communications that do not serve to underwrite a public communicative sphere. A paradigmatic example might be communications that occur within "fiduciary, person-to-person relationships.",99

92. For attempted regulation of advertisements in newspapers, see, for example, 44 Liquormart, Inc. v. Rhode Island, 517 U.S. 484, 490-91 (1996). See generally Zauderer v. Office of Disciplinary Counsel, 471 U.S. 626 (1985); In re R.M.J., 455 U.S. 191 (1982); Bates v. State Bar of Ariz., 433 U.S. 350 (1977).

93. Post, supra note 37, at 1276.

94. Carroll D. Clark, Concept of the Public, 13 Sw. SOC. SCI. Q. 311, 313 (1933).

95. JOHN W. BENNETT \& MELVIN M. TUMIN, SOCIAL LIFE: STRUCTURE AND FUNCTION 140 (1948).

96. See Post, supra note 37, at 1276.

97. E.B. REUTER \& C.W. HART, INTRODUCTION TO SOCIOLOGY 445 (1933).

98. See Post, Constitutional Concept, supra note 25, at 633-44, 672-76.

99. Lowe v. SEC, 472 U.S. 181, 210 (1985). 
Although the communication between a professional and her client might concern commercial matters, its regulation would almost certainly not be conceptualized as an issue of First Amendment commercial speech doctrine. This suggests that we should distinguish between "impersonal" communications that sustain a public of independent strangers, and "personalized communications" that constitute particular relationships of dependence. ${ }^{100}$

Such a distinction allows us to see that the Court's narrow focus on "informational function"101 is radically insufficient to define the First Amendment category of commercial speech. In speaking with their clients, lawyers undoubtedly convey information relevant to the exercise of citizenship, and yet such communications would not normally come within the purview of commercial speech doctrine. The doctrine seems to protect only the distribution of commercial information that reinforces a public communicative sphere by addressing strangers who are presumed to be independent and self-possessed. The doctrine stops short of commercial communications between persons deemed to be involved in relationships of dependence or reliance. ${ }^{102}$

If we imagine the pharmacist's impersonal newspaper advertisements and the lawyer's personal advice to her clients as the opposite poles of a spectrum, we can perhaps envision how more difficult cases might be analyzed. So, for example, consumer product safety warnings are distributed to the public at large, but they are not regarded as commercial speech because consumers

100. Id.

101. Cent. Hudson Gas \& Elec. Corp. v. Pub. Serv. Comm'n, 447 U.S. 557, 563 (1980).

102. For a discussion of these presumptions as thresholds to certain kinds of First Amendment protection, see Post, supra note 37, at 1254-55. For an effort to draw this line, see the remarks of Justice Byron White:

One who takes the affairs of a client personally in hand and purports to exercise judgment on behalf of the client in the light of the client's individual needs and circumstances is properly viewed as engaging in the practice of a profession. Just as offer and acceptance are communications incidental to the regulable transaction called a contract, the professional's speech is incidental to the conduct of the profession. If the government enacts generally applicable licensing provisions limiting the class of persons who may practice the profession, it cannot be said to have enacted a limitation on freedom of speech or the press subject to First Amendment scrutiny. Where the personal nexus between professional and client does not exist, and a speaker does not purport to be exercising judgment on behalf of any particular individual with whose circumstances he is directly acquainted, government regulation ceases to function as legitimate regulation of professional practice with only incidental impact on speech; it becomes regulation of speaking or publishing as such, subject to the First Amendment's command that "Congress shall make no law ... abridging the freedom of speech, or of the press."

Lowe, 472 U.S. at 232 (White, J., concurring) (footnotes omitted). For a good discussion, see Halberstam, supra note 6, at 839-44. 
in such contexts are presumed to be dependent and justifiably reliant upon the care of manufacturers. ${ }^{103}$

By contrast, expression classified as commercial speech is sometimes disseminated to particular persons, rather than to the public at large. ${ }^{104}$ In such contexts, however, the Court is careful to assure itself that the strangers who are addressed by a solicitation are able to "assess the value of the information presented"105 without the "dangers of compromised independence." The Court seeks to ascertain whether the circumstances of the solicitation are "conducive to rational and considered decisionmaking."107 If the context of an individualized solicitation is deemed inconsistent with rational independence, the Court will deprive the solicitation of the First Amendment protection of commercial speech doctrine, citing the possibility of "fraud, undue influence, intimidation," or "overreaching,"108

We can thus see that implicit within commercial speech doctrine lies a set of significant but largely unarticulated assumptions about the context in which the Court will use the First Amendment to ensure that "the stream of commercial information" flows "freely."109 The Court will intervene only when the stream of information flows among strangers who can be conceived as independent and rational. We can interpret this as a constitutional requirement that information must be dispersed under conditions that are constitutive of a public communicative sphere.

When information is exchanged in circumstances that are deemed inconsistent with this sphere, because persons are implicated in relationships of dependence or reliance requiring legal protection, the Court has not applied commercial speech doctrine. It has tended instead to regard the exchange of information within such relationships as "linked inextricably'

103. See, e.g., Pavlides v. Galveston Yacht Basin, Inc., 727 F.2d 330, 338-39 (5th Cir. 1984); Knaysi v. A.H. Robins Co., 679 F.2d 1366, 1369 (11th Cir. 1982).

104. See Edenfield v. Fane, 507 U.S. 761, 763-64 (1993). Similarly, the Court will sometimes regard as public discourse speech directed only at particular persons, as the Court's invocation of "the lonely pamphleteer who uses carbon paper or a mimeograph" suggests, so long as the speech is distributed in a way-as for example to strangers-that suggests its target to be the public at large. Branzburg v. Hayes, 408 U.S. 665, 704 (1972).

105. Edenfield, 507 U.S. at 767.

106. Id. at 772 .

107. Id. at 775 .

108. Ohralik v. Ohio State Bar Ass'n, 436 U.S. 447, 462 (1978); see Edenfield, 507 U.S. at 775 (noting the danger of "uninformed acquiescence"); Shapero v. Ky. Bar Ass'n, 486 U.S. 466, 474 (1988); Zauderer v. Office of Disciplinary Counsel, 471 U.S. 626, 642 (1985) (holding that regulation is permissible to avoid "undue influence" or "pressure" that is not "conducive to reflection and the exercise of choice").

109. Va. State Bd. of Pharmacy v. Va. Consumer Council, Inc., 425 U.S. 748, 771-72 (1976); see Edenfield, 507 U.S. at 768. 
with the commercial arrangement"110 in which it occurs, so that regulation of the arrangement can also restrict the speech by which the arrangement is constituted.

\section{PROTECTING COMMERCIAL SPEeCH}

We can now formulate a somewhat more comprehensive account of the First Amendment category of commercial speech. We can define it as the set of communicative acts about commercial subjects that within a public communicative sphere convey information of relevance to democratic decision making but that do not themselves form part of public discourse. This definition, in turn, should illuminate our consideration of Van Alstyne's second question, which asks what difference it makes that a speech act is classified as commercial speech. Constitutional protections for the category of commercial speech ought to be explicable in terms of the constitutional values the category is created to serve.

Commercial speech doctrine is a sprawling, complex, and contentious area of jurisprudence, and it is certainly not my ambition to propose a systematic reconstruction of its structure and rules. My hope instead is simply to illustrate that many of the doctrinal rules that establish the subordinate status of commercial speech can be explained by the difference between valuing speech as a form of participation in public discourse, and valuing speech merely for the information it conveys.

To find a path through this large and amorphous topic, 1 divide commercial speech doctrine into two parts. First, I discuss rules articulated at the very origins of commercial speech doctrine that describe the kinds of regulations that may be imposed upon commercial speech, but not upon public discourse. There are a number of such rules that have endured with stability and resilience, but 1 shall discuss only three of them: those that (1) empower states to compel disclosures within the domain of commercial speech, ${ }^{\prime \prime \prime}$ (2) suspend overbreadth doctrine within the domain of commercial speech, ${ }^{112}$ and (3) suspend prior restraint doctrine within the domain of commercial speech. ${ }^{113}$ Second, 1 discuss the canonical standard used to assess the constitutionality of regulations that are imposed upon commercial

110. Edenfield, 507 U.S. at 767 (quoting Friedman v. Rogers, 440 U.S. 1, 10 n.9 (1979)); see Lowe v. SEC, 472 U.S. 181, 228-29 (1985) (White, J., concurring).

111. See Va. Pharmacy, 425 U.S. at 772 n.24.

112. See Bates v. State Bar of Ariz., 433 U.S. 350, 380-81 (1977).

113. See Va. Pharmacy, 425 U.S. at 772 n.24. 
speech. This is, of course, the controversial but still regnant multipart test first set forth in 1980 in Central Hudson. ${ }^{114}$

\section{A. Rules that Subordinate Commercial Speech}

\section{Compelled Disclosures}

The First Amendment ordinarily prohibits the state from regulations that compel speech within public discourse. ${ }^{115}$ The Court has observed that "[t]here is certainly some difference between compelled speech and compelled silence, but in the context of protected speech, the difference is without constitutional significance, for the First Amendment guarantees 'freedom of speech,' a term necessarily comprising the decision of both what to say and what not to say."116 The essential point is that "[m]andating speech that a speaker would not otherwise make necessarily alters the content of the speech," ${ }^{117}$ and "[t]he First Amendment mandates that we presume that speakers, not the government, know best both what they want to say and how to say it.".118

This rule does not apply, however, within the domain of commercial speech. In Virginia Pharmacy the Court held that commercial speech could be required to "include such additional information, warnings, and disclaimers, as are necessary to prevent its being deceptive."119 And in Zauderer v. Office of Disciplinary Counsel, ${ }^{120}$ the Court upheld a state requirement that attorney advertisements contain particular disclosures. The Court reasoned:

In requiring attorneys who advertise their willingness to represent clients on a contingent-fee basis to state that the client may have to bear certain expenses even if he loses, Ohio has not attempted to prevent attorneys from conveying information to the public; it has only required them to provide somewhat more information than they might otherwise be inclined to present. We have, to be sure, held that

114. See Cent. Hudson Gas \& Elec. Corp. v. Pub. Serv. Comm'n, 447 U.S. 557, 566 (1980).

115. Such regulations are viewed as content based and hence subject "to exacting First Amendment scrutiny." Riley v. Nat'l Fed'n of the Blind, 487 U.S. 781, 798 (1988).

116. Id. at 796-97. In Riley the Court upheld its previous precedents to the effect that charitable solicitation was public discourse rather than commercial speech. See id. at 787-88. 1t therefore struck down a state law mandating that professional charitable fund raisers disclose to potential donors the average percentage of gross receipts actually turned over to charities. See id. at 803 .

117. Id. at 795 .

118. Id. at 790-91. For recent examples of the Court's prohibition of compelled speech, see Hurley v. Irish-American Gay, Lesbian $\mathcal{B}$ Bisexual Group of Boston, Inc., 515 U.S. 557, 581 (1995), and McIntyre v. Ohio Elections Commission, 514 U.S. 334, 357 (1995).

119. Va. State Bd. of Pharmacy v. Va. Consumer Council, Inc., 425 U.S. 748, 772 n.24 (1976).

120. 471 U.S. $626(1985)$. 
in some instances compulsion to speak may be as violative of the First Amendment as prohibitions on speech....

... Ohio has not attempted to "prescribe what shall be orthodox in politics, nationalism, religion, or other matters of opinion or force citizens to confess by word or act their faith therein." The State has attempted only to prescribe what shall be orthodox in commercial advertising, and its prescription has taken the form of a requirement that appellant include in his advertising purely factual and uncontroversial information about the terms under which his services will be available. Because the extension of First Amendment protection to commercial speech is justified principally by the value to consumers of the information such speech provides, appellant's constitutionally protected interest in not providing any particular factual information in his advertising is minimal.

... [W]e hold that an advertiser's rights are adequately protected as long as disclosure requirements are reasonably related to the State's interest in preventing deception of consumers. ${ }^{121}$

The doctrinal discrepancy between public discourse and commercial speech could not be sharper. But what explains this discrepancy? The First Amendment strongly disfavors compelled disclosure requirements within public discourse because such requirements are understood to infringe the autonomy of speakers in determining the content of their speech. Disclosure requirements are permissible within the domain of commercial speech, however, because the autonomy of speakers is not at stake, only the conveyance of information. Hence commercial speech doctrine accords only "minimal" value to the interests of speakers "in not providing any particular factual information."

The doctrinal discrepancy between public discourse and commercial speech accurately reflects the distinct First Amendment values that are understood to be at stake in these two different forms of speech. Public discourse is where citizens attempt to render the state responsive to their views, and hence where individual and collective self-determination is reconciled. ${ }^{122}$ In such circumstances, compulsory speech disrupts the very point of public discourse, for it threatens to compromise "the values lying at the "heart of the First Amendment the notion that an individual should be free to believe as he will, and that in a free society one's beliefs should be shaped by his mind and his conscience rather than coerced by the State." ${ }^{123}$

121. Id. at 650-51 (citations omitted) (quoting W. Va. State Bd. of Educ. v. Barnette, 319 U.S. $624,642(1943))$.

122. See Post, supra note 11, at 173.

123. Glickman v. Wileman Bros. \& Elliott, lnc., 521 U.S. 457, 472 (1997) (quoting Abood v. Detroit Bd. of Educ., 431 U.S. 204, 234-35 (1977)). 
Within commercial speech, by contrast, the primary constitutional value concerns the circulation of accurate and useful information. For the state to mandate disclosures designed more fully and completely to convey information is thus to advance, rather than to contradict, pertinent constitutional values.

\section{Overbreadth Doctrine}

State regulations of public discourse are subject to overbreadth analysis, but "the First Amendment overbreadth doctrine does not apply to" commercial speech. ${ }^{124}$ This is an important point of difference, but its significance is somewhat obscured by the fact that overbreadth analysis itself is so various and ambiguous.

It is sufficient for our purposes to distinguish between two different meanings of overbreadth doctrine. First, overbreadth can refer to the form of a legal rule. To say that a legal rule is overbroad is to say that it is overinclusive, that its provisions regulate more behavior than can or should strictly be regulated. ${ }^{125}$ We use the term "overbreadth" in this way whenever we speak of "overbroad statute[s]."

Second, overbreadth can refer to the ability of a person to strike down a statute on its face, even if the statute's specific application to him might be constitutional. Overbreadth in this sense is often referred to as a doctrine of third-party standing designed to avoid the chilling effect that might occur when a statute is unconstitutional in many of its applications but is without proper plaintiffs to challenge it. ${ }^{127}$ I separately discuss each of these meanings of the overbreadth doctrine.

124. Shapero v. Ky. Bar Ass'n, 486 U.S. 466, 478 (1988) (Brennan, J., plurality opinion); accord Bd. of Trs. v. Fox, 492 U.S. 469, 481 (1989); Ohralik v. Ohio State Bar Ass'n, 436 U.S. 447, 462 n.20 (1978).

125. For examples of this usage, see Massachusetts v. Oakes, 491 U.S. 576, 586-88 (1989) (Scalia, J., plurality opinion), and Brockett v: Spokane Arcades, Inc., 472 U.S. 491, 503 (1985).

126. See, e.g., Osborne v. Ohio, 495 U.S. 103, 118-19 (1990); Bates v. State Bar of Ariz., 433 U.S. 350, 380 (1977); Erznoznik v. City of Jacksonville, 422 U.S. 205, 216 (1975).

127. See Broadrick v. Oklahoma, 413 U.S. 601, 610-13 (1973). There is also a third meaning of overbreadth doctrine, which refers to the actual operation of a legal rule. To say that a legal rule is overbroad in this sense is to say that, regardless of its precise drafting, its actual effect is to inhibit the exercise of otherwise protected First Amendment freedoms. Justice William Brennan coined the term "overbreadth" in NAACP v. Button, 371 U.S. 415, 433 (1963), to describe just this kind of situation. It is not, however, pertinent to our consideration of commercial speech doctrine, and so 1 have omitted it. 


\section{a. Overbreadth as Overinclusiveness}

Overbreadth in the sense of overinclusiveness concerns the question of how narrowly tailored a legal rule must be. Overinclusiveness is a matter of degree, and the Court has made clear that it is prepared to accept greater overinclusiveness in the domain of commercial speech than in the arena of public discourse. Within public discourse, the Court has said that "[p]recision of regulation must be the touchstone in an area so closely touching our most precious freedoms. ${ }^{128}$ Considerably greater latitude is allowed within the domain of commercial speech, however, where it is said that "[w]hat our decisions require is a 'fit' between the legislature's ends and the means chosen to accomplish those ends, a fit that is not necessarily perfect, but reasonable; that represents not necessarily the single best disposition but one whose scope is 'in proportion to the interests served."'129

The contrast between the two standards can be seen by comparing the Court's judgments in two cases decided on the same day: Ohralik v. Ohio State Bar Association ${ }^{130}$ and In re Primus. ${ }^{131} \ln$ Ohralik, the Court upheld a broad prophylactic ban on in-person solicitation by lawyers. ${ }^{132}$ It noted that the ban was justified by inherent dangers of overreaching and undue influence, and it held that the ban could be applied to a particular lawyer even though the state had not demonstrated that the lawyer had himself engaged in any such misconduct. ${ }^{133}$ In Primus, by contrast, the Court held that in-person solicitation of public interest litigation by an American Civil Liberties Union

128. Button, 371 U.S. at 438.

129. Fox, 492 U.S. at 480 (citations omitted) (quoting In re R.M.J., 455 U.S. 191, 203 (1982)). There is actually a great deal of play in the joints about how overinclusive a legal regulation may be in the area of commercial speech. Compare Edenfield v. Fane, 507 U.S. 761, 769 (1993), and Peel v. Attorney Registration \& Disciplinary Comm'n, 496 U.S. 91, 107 (1990) (Stevens., J.), and Shapero, 486 U.S. at 476, and Zauderer v. Office of Disciplinary Counsel, 471 U.S. 626, 649 (1985), with Ohralik, 436 U.S. at 464.

130. 436 U.S. 447 (1978).

131. 436 U.S. 412 (1978).

132. See Ohralik, 436 U.S. at 464.

133. See id. at 465-70. The lawyer argued "that nothing less than actual proved harm to the solicited individual would be a sufficiently important state interest to justify disciplining the attorney who solicits employment in person for pecuniary gain." Id: at 464 . But the Court said that the lawyer's "argument misconceives the nature of the State's interest." $1 d$.

The Rules prohibiting solicitation are prophylactic measures whose objective is the prevention of harm before it occurs. The Rules were applied in this case to discipline a lawyer for soliciting employment for pecuniary gain under circumstances likely to result in the adverse consequences the State seeks to avert. In such a situation, which is inherently conducive to overreaching and other forms of misconduct, the State has a strong interest in adopting and enforcing rules of conduct designed to protect the public from harmful solicitation by lawyers whom it has licensed.

Id. 
lawyer was to be regarded as public discourse, rather than as commercial speech, and hence that it could not be regulated by such an overbroad rule.

The approach we adopt today in Ohralik, that the State may proscribe in-person solicitation for pecuniary gain under circumstances likely to result in adverse consequences, cannot be applied to appellant's activity on behalf of the ACLU.

At bottom, the case against appellant rests on the proposition that a State may regulate in a prophylactic fashion all solicitation activities of lawyers because there may be some potential for overreaching... whenever a lawyer gives unsolicited advice and communicates an offer of representation to a layman. Under certain circumstances, that approach is appropriate in the case of speech that simply "propose[s] a commercial transaction." In the context of political expression and association, however, a State must regulate with significantly greater precision. ${ }^{134}$

Notice that the state's interest in protecting clients is exactly the same in Ohralik and in Primus. Because the significance of the state's interest is held constant, the distinction between the degree of overinclusiveness allowed by the two cases must reflect a difference in the constitutional value of the speech that the state seeks to regulate. A Meiklejohnian model of the First Amendment cannot explain this difference, for it regards all speech as constitutionally valuable because of the information it provides for public decision making. We need instead a theory of the First Amendment capable of recognizing that public discourse implicates different constitutional values than does commercial speech.

1 have already suggested that the participatory model of self-governance offers such an account, because it allows us to see that public discourse exemplifies the constitutional value of democratic legitimation, while commercial speech does not. Both public discourse and commercial speech convey information relevant to democratic decision making, but because public discourse is also a venue of democratic participation, overinclusive starutes do more constitutional damage when applied to public discourse than when

134. Primus, 436 U.S. at 434, 437-38 (alteration in original) (citations omitted). It should be noted, however, that within public discourse the Court has only required "precision" of regulation for legal rules that are content based. Content-neutral time, place, and manner regulations are permitted approximately the same degree of overinclusiveness as are regulations of commercial speech. See Fox, 492 U.S. at 477-78; Post, supra note 37, at 1260-63. But regulations of commercial speech are characteristically content based, and so, like the regulation at issue in Ohralik, tend to be too imprecise to withstand the strict scrutiny they would receive were they to be imposed upon public discourse. 
applied to commercial speech. Applied to public discourse, overinclusive statutes endanger the precious and fragile value of democratic engagement. This value is not at risk in the regulation of commercial speech.

\section{b. Overbreadth as Third-Party Standing}

The doctrine of overbreadth refers not only to the overinclusiveness of legal rules, but also to the question of whether "a party whose own conduct is not protected by the First Amendment" can "challenge a regulation as" overinclusive "because of its impact on parties not before the Court."135 The justification for this branch of overbreadth doctrine is that an overinclusive statute

might serve to chill protected speech. First Amendment interests are fragile interests, and a person who contemplates protected activity might be discouraged by the in terrorem effect of the statute... The use of overbreadth analysis reflects the conclusion that the possible harm to society from allowing unprotected speech to go unpunished is outweighed by the possibility that protected speech will be muted. ${ }^{136}$

This aspect of overbreadth doctrine, which might be termed overbreadth standing analysis, is said to be categorically inapplicable to commercial speech. ${ }^{137}$ The reason given by the Court for this exclusion is that "commercial speech may be more durable than other kinds. Since advertising is the sine qua non of commercial profits, there is little likelihood of its being chilled by proper regulation and foregone entirely."138 "[C]ommercial speech is more hardy, less likely to be 'chilled,' and not in need of surrogate litigators." ${ }^{139}$

This reasoning relies upon an empirical account of the actual durability of commercial speech, an account that does "not survive close examination."140 Many forms of public discourse are fueled by an intense and hardy search for profits: motion pictures, books, magazines, and newspapers, to mention only

135. Peel v. Attorney Registration \& Disciplinary Comm'n, 496 U.S. 91,107 n.15 (1990) (Stevens., J.). For a typical example of confusion between the two senses of overbreadth, see id. at 118-19 (White, J., dissenting).

136. Bates v. State Bar of Ariz., 433 U.S. 350, 380 (1977).

137. See id.

138. Va. State Bd. of Pharmacy v. Va. Consumer Council, lnc., 425 U.S. 748, 771 n.24 (1976); see Bates, 433 U.S. at 381 ("Since advertising is linked to commercial well-being, it seems unlikely that such speech is particularly susceptible to being crushed by overbroad regulation.").

139. Fox, 492 U.S. at 481. "Commercial speech is not as likely to be deterred as noncommercial speech, and therefore does not require the added protection afforded by the overbreadth approach." Ohralik v. Ohio State Bar Ass'n, 436 U.S. 441, 462 n.20 (1978); see Friedman v. Rogers, 440 U.S. 1,10 (1979).

140. Farber, supra note 20, at 385-86. 
a few. ${ }^{141}$ The chilling effect of regulation, moreover, "depends as much on the potential penalty as on the motivation for the speech. A five dollar fine in a political speech case is probably less of a deterrent than a jail sentence -or disbarment-in a commercial speech case. ${ }^{142}$

At most, therefore, it might be argued that commercial speech is perhaps relatively less likely to be chilled than public discourse, and the empirical basis of even such a tepid generalization is quite shaky. The argument certainly does not justify a rule that categorically forbids applying overbreadth standing analysis to commercial speech. It is more plausible to understand the categorical nature of this exclusion as expressing the perspective that we have already applied to the overinclusiveness branch of overbreadth doctrine. Overbreadth standing analysis is categorically excluded from commercial speech doctrine because of the constitutional quality of the speech that might be chilled, rather than because of its empirical quantity.

To chill commercial speech is to lose information. No other constitutional value is at stake. Information is fungible. The central insight of Meiklejohnian analysis is that it does not matter which speaker provides information, so long as it is provided. If a particular speaker is chilled, therefore, it is quite possible that equivalent information will become available from other sources.

If public discourse is chilled, by contrast, not only is information lost, but also the possibility of democratic legitimation. Democratic legitimation is not fungible; it is earned, speaker by speaker. A person whose participation within public discourse has been chilled has by hypothesis become that much more alienated from the state. This important difference might well explain why the Court categorically applies overbreadth standing analysis to public discourse, but not to commercial speech.

\section{Prior Restraint Doctrine}

There are heavy presumptions against imposing prior restraints upon public discourse. ${ }^{143}$ But in Virginia Pharmacy, Justice Blackmun specifically notes that these presumptions might be "inapplicable" to commercial speech. ${ }^{14}$ In Central Hudson, the Court even recommends a system of prior restraints as an acceptable method of regulating commercial speech. ${ }^{145}$ The Court thus

141. See Kozinski \& Banner, supra note 3, at 637.

142. Farber, supra note 20, at 386.

143. See N.Y. Times Co. v. United States, 403 U.S. 713, 714 (1971); Org. for a Better Austin v. Keefe, 402 U.S. 415,419 (1971).

144. Va. State Bd. of Pharmacy v. Va. Consumer Council, lnc., 425 U.S. 748, 772 n.24

(1976); see Friedman, 440 U.S. at 10.

145. See Cent. Hudson Gas \& Elec. Corp. v. Pub. Serv. Comm'n, 447 U.S. 557, 571 (1980). 
seems to have created a doctrinal structure in which prior restraints are presumptively unconstitutional within public discourse, but presumptively. constitutional for commercial speech.

A difficulty in explaining this discrepancy lies in the knotted and ambiguous nature of prior restraint doctrine, for it is hard to ascertain exactly what values the doctrine is meant to serve. ${ }^{146}$ A plausible account, however, is offered by the Court in Pittsburgh Press Co. v. Pittsburgh Commission on Human Relations, ${ }^{147}$ in which the Court asserts that "[t]he special vice of a prior restraint is that communication will be suppressed, either directly or by inducing excessive caution in the speaker, before an adequate determination that it is unprotected by the First Amendment." ${ }^{\text {148 }}$

Although this reasoning cannot begin to provide a full explanation of the entire range of prior restraint doctrine, ${ }^{149}$ it does seem pertinent to the Court's refusal to apply the doctrine to the area of commercial speech. The Court has explicitly remarked that "[w]e have observed that commercial speech is such a sturdy brand of expression that traditional prior restraint doctrine may not apply to it."150 We can thus interpret the Court's refusal to apply prior restraint doctrine to commercial speech as resting on the notion that commercial speech is too durable to be chilled by prior restraints.

If this is the Court's reasoning, the same explanation that we have already articulated with regard to overbreadth standing analysis applies to prior restraint doctrine. The empirical assertion that commercial speech is more sturdy than public discourse is suspect, but the chilling of public discourse poses distinctive and more significant threats to central constitutional values than does the chilling of commercial speech. The differential application of prior restraint doctrine, therefore, expresses the constitutional distinction between communication valued only as information and communication valued as constitutive of democratic self-government.

146. See, e.g., Stephen R. Barnett, The Puzzle of Prior Restraint, 29 STAN. L. REV. 539 (1977); Vince Blasi, Prior Restraints on Demonstrations, $68 \mathrm{MICH}$. L. REV. 1482 (1970); Vincent Blasi, Toward a Theory of Prior Restraint: The Central Linkage, 66 MINN. L. REV. 11 (1981); John Calvin Jeffries, Jr., Rethinking Prior Restraint, 92 YALE L.J. 409 (1983); Martin H. Redish, The Proper Role of the Prior Restraint Doctrine in First Amendment Theory, 70 VA. L. REV. 53 (1984).

147. 413 U.S. 376 (1973).

148. Id. at 390 .

149. In a case like New York Times Co. v. United States, 403 U.S. 713 (1971), for example, the proposed injunction of the Court could not possibly have resulted in a chilling effect, because the injunction would have extended only to specific materials before the Court, as to which a full judicial examination had already been conducted. Yet the proposed injunction was regarded as a disfavored prior restraint.

150. Cent. Hudson, 447 U.S. at 571 n.13. 


\section{B. The Central Hudson Test}

After a period of much controversy, the Court in 1980 in Central Hudson articulated a general test for determining the constitutionality of regulations of commercial speech. ${ }^{151}$ Although the test has subsequently been interpreted from radically different perspectives, ${ }^{152}$ and although it has been attacked by numerous justices, ${ }^{153}$ it has nevertheless remained the dominant test. ${ }^{154}$ The test provides:

In commercial speech cases, then, a four-part analysis has developed. At the outset, we must determine whether the expression is protected by the First Amendment. For commercial speech to come within that provision, it at least must concern lawful activity and not be misleading. Next, we ask whether the asserted governmental interest is substantial. If both inquiries yield positive answers, we must determine whether the regulation directly advances the governmental interest asserted, and whether it is not more extensive than is necessary to serve that interest. ${ }^{155}$

The Central Hudson test can be divided into two parts. The first part of the test articulates threshold conditions for the application of First Amendment protections. The second part of the test enunciates the nature of these protections. 1 discuss each of these parts separately. My concern is to explore how the various aspects of the Central Hudson test can best be interpreted to reflect the underlying First Amendment theory that justifies constitutional protections for commercial speech.

\section{The Threshold Requirements}

The Central Hudson test imposes two threshold requirements before commercial speech can receive First Amendment protection. The speech must concern lawful activity, and it must not be misleading.

In this brief Lecture I do not discuss the requirement of lawful activity. Within public discourse, the advocacy of illegal actions cannot be sanctioned "except where such advocacy is directed to inciting or producing imminent

151. See id. at 566 .

152. Compare, e.g., Posadas de P.R. Assocs. v. Tourism Co., 478 U.S. 328 (1986), with Rubin v. Coors Brewing Co., 514 U.S. 476 (1995). See Matthew Miller, The First Amendment and Legislative Bans of Liquor and Cigarette Advertisements, 85 COLUM. L. REV. 632, 633-35 (1985); Brian J. Waters, Comment, A Doctrine in Disarray: Why the First Amendment Demands the Abandonment of the Central Hudson Test for Commercial Speech, 27 SETON HALL L. REV. 1626, 1628 (1997).

153. See, e.g., 44 Liquormart, Inc. v. Rhode Island, 517 U.S. 484, 523-28 (1996) (Thomas, J., concurring).

154. See, e.g., Greater New Orleans Broad. Ass'n v. United States, 527 U.S. 173, 183 (1999).

155. Cent. Hudson, 447 U.S. at 566. 
lawless action and is likely to incite or produce such action."156 In an early case, the Court actually used this test to shield commercial speech from regulation on the ground that it advertised potentially illegal action. ${ }^{157}$ But the Central Hudson test has since drawn a bright line between commercial speech and public discourse with regard to speech connected to illegal action.

Some have argued that this line is illusory, because soliciting illegal action is flatly unprotected even within public discourse. ${ }^{158}$ But there does seem to be an important difference between advocating illegal action and soliciting illegal action, and much commercial speech would appear closer to the former than the latter. Apart from stressing the obvious (and to me significant) constitutional difference between penalizing the dissemination of information about illegal acts and penalizing participation in the process of democratic self-governance because of a possible connection to illegal acts, however, I observe only that this is a dense and obscure area that is best left to another day.

Instead I focus on the threshold requirement that commercial speech cannot receive First Amendment protection if it is "misleading."159 To analyze this requirement, we must distinguish speech that is factually false from speech that is merely misleading. With respect to false speech, the Court has stated that "there is no constitutional value in false statements of fact." ${ }^{\prime 60}$ Although the dissemination of false facts within public discourse is most often protected in order to avoid chilling the communication of otherwise protected speech, ${ }^{161}$ the Court has refused to apply this kind of chilling analysis to commercial speech. ${ }^{162}$ The lack of constitutional protection for false statements of fact has consequently had more dramatic effects in the realm of commercial speech.

Of much greater theoretical importance, however, is the distinction between commercial speech and public discourse with regard to the regulation of misleading speech. Within the area of public discourse, the Court has

156. Brandenburg v. Ohio, 395 U.S. 444, 447 (1969). For a discussion of Brandenburg, see KENT GREENAWALT, SPEECH, CRIME, AND THE USES OF LANGUAGE (1989), and Larry Alexander, Incitement and Freedom of Speech, in FREEDOM OF SPEECH AND INCITEMENT AGAINST DEMOCRACY 101 (David Kretzmer \& Francine Kershman Hazan eds., 2000).

157. See Carey v. Population Servs. 1nt'l, 431 U.S. 678, 701 (1977).

158. See, e.g., Sullivan, supra note 3 , at 152.

159. "[F]alse, deceptive, or misleading commercial speech may be banned." Ibanez v. Fla. Dep't of Bus. \& Prof'l Regulation, 512 U.S. 36, 142 (1994).

160. Gertz v. Robert Welch, Inc., 418 U.S. 323, 340 (1974).

161. See, e.g., St. Amant v. Thompson, 390 U.S. 727, 732 (1968); N.Y. Times Co. v. Sullivan, 376 U.S. 254, 279, 283 (1964).

162. See supra notes 135-139 and accompanying text. 
been clear that "there is no such thing as a false idea." ${ }^{\text {"63 }}$ But under the Central Hudson test, misleading commercial speech does not merit any First Amendment protection at all. ${ }^{164}$ This is said to be because " [t] $]$ he First Amendment ... does not prohibit the State from insuring that the stream of commercial information flow[s] cleanly as well as freely.'"165

Withholding First Amendment protection from misleading speech appears on its face inconsistent with the Meiklejohnian theory that justifies constitutional protection for commercial speech. Meiklejohn famously believed that there was an "equality of status in the field of ideas." ${ }^{166}$ Imagine, for example, the moderator at a Meiklejohnian town meeting ruling a speaker out of order because his ideas were "misleading." Meiklejohn would have been appalled:

When men govern themselves, it is they-and no one else-who must pass judgment upon unwisdom and unfairness and danger. And that means that unwise ideas must have a hearing as well as wise ones, unfair as well as fair, dangerous as well as safe, un-American as well as American. Just so far as, at any point, the citizens who are to decide an issue are denied acquaintance with information or opinion or doubt or disbelief or criticism which is relevant to that issue, just so far the result must be ill-considered, ill-balanced planning for the general good. ${ }^{167}$

The threshold requirement that commercial speech not be misleading is especially striking because the Court's justification for it is so very weak. The Court has sought to explain the requirement on the grounds that "[t]he truth of commercial speech ... may be more easily verifiable by its dissemi-

163. Gertz, 418 U.S. at 339; see, e.g., Cent. Hudson Gas \& Elec. Corp. v. Pub. Serv. Comm'n, 447 U.S. 557, 598 (1980) (Rehnquist, J., dissenting).

[1]n the world of political advocacy and its marketplace of ideas, there is no such thing as a

"fraudulent" idea: there may be useless proposals, totally uniworkable schemes, as well as very sound proposals that will receive the imprimatur of the "marketplace of ideas" through our majoritarian system of election and representative government.

Id.; see Shiffrin, supra note 20, at 1231.

164. See, e.g., In re R.M.J., 455 U.S. 191 (1982).

Truthful advertising related to lawful activities is entitled to the protections of the First

Amendment. But when the particular content or method of the advertising suggests that it is inherently misleading or when experience has proved that in fact such advertising is subject to abuse, the States may impose appropriate restrictions. Misleading advertising may be prohibited entirely. But the States may not place an absolute prohibition on certain types of potentially misleading information ... if the information also may be presented in a way that is not deceptive.

Id. at 203.

165. Edenfield v. Fane, 507 U.S. 761, 768 (1993) (quoting Va. State Bd. of Pharmacy v. Va.

Citizens Consumer Council, lnc., 425 U.S. 748, 771-72 (1976)).

166. MEIKLEJOHN, supra note 53, at 27.

167. Id. 
nator than, let us say, news reporting or political commentary, in that ordinarily the advertiser seeks to disseminate information about a specific product or service that he himself provides and presumably knows more about than anyone else." 168 But this explanation, like the hypothetical durability that the Court has attributed to commercial speech, has been persuasively criticized.

Putting aside outright false communications, the difficulties of identifying misleading statements seem as formidable in the area of commercial speech as in the arena of public discourse. ${ }^{169}$ Indeed, the Court has itself acknowledged as much.

A brief survey of the body of case law that has developed as a result of the Federal Trade Commission's efforts to carry out its mandate under $\$ 5$ of the Federal Trade Commission Act to eliminate "unfair or deceptive acts or practices in... commerce," reveals that distinguishing deceptive from nondeceptive advertising in virtually any field of commerce may require resolution of exceedingly complex and technical factual issues and the consideration of nice questions of semantics. $^{170}$

Especially in an age of "product-image and product-personality advertising," the notion that commercial speech is any more verifiable than public discourse has a rather quaint air about it, as though nostalgic for an era before "advertising entered the twentieth century."

Stripped of this unconvincing justification, the withholding of First Amendment protection from misleading commercial speech appears puzzling, because it seems inconsistent with the very theory articulated by the Court to justify constitutionally protecting commercial speech. The Court has, however, used the Central Hudson test's misleading requirement in two distinct ways, and at least one of these can be rendered compatible with the Meiklejohnian foundations of commercial speech doctrine.

168. Va. Pharmacy, 425 U.S. at 772 n.24; see Rubin v. Coors Brewing Co., 514 U.S. 476 (1995).

Most of the time, if a seller is representing a fact or making a prediction about his product, the seller will know whether his statements are false or misleading and he will be able to correct them. On the other hand, the purveyor of political speech is more often ... an observer who is in a poor position to verify its truth.

Id. at $495 \mathrm{n} .4$ (Stevens, J., concurring in the judgment).

169. See, e.g., Farber, supra note 20 , at 385-86.

170. Zauderer v. Office of Disciplinary Counsel, 471 U.S. 626, 645 (1985) (citation omitted).

171. Ronald K.L. Collins \& David M. Skover, Commerce $\mathcal{E}$ Communication, 71 TEX. L. REV. 697, 702 (1993).

172. Kozinski \& Banner, supra note 3, at 635 . How, for example, might the misleading quality of "the claim that Burger King's hamburgers taste better than McDonalds' because they are charbroiled" be evaluated? Id. 
Meiklejohn imagined the town meeting as an assembly "of free and equal men." ${ }^{173}$ Implicit within the public communicative sphere, which defines the limits of commercial speech, are similar presuppositions. ${ }^{174}$ There are many social settings, however, in which persons are neither equal nor free, but rather unequal and dependent. A paradigmatic example might be the reliance of a patient upon the advice of his doctor. The Court has sometimes used the misleading requirement to identify such circumstances and to deprive them of the constitutional protection of commercial speech doctrine on the grounds that they "pose dangers that the State has a right to prevent," like "uninformed acquiescence." "175

Used in this way, the misleading requirement refers not to the content of speech, but to the structural relationship between a speaker and her audience. Thus the Court has used the requirement to distinguish between "in-person solicitation" and "print advertising," holding that the latter "poses much less risk of overreaching or undue influence" because it is "more conducive to reflection and the exercise of choice on the part of the consumer than is personal solicitation." ${ }^{176}$ In this context, the misleading requirement articulates the prerequisites for the public communicative sphere that underwrites the very constitutional category of commercial speech. It is therefore appropriate to use the requirement as a threshold precondition for First Amendment protection under the Central Hudson test.

But the Court has sometimes deployed the misleading requirement in a second and altogether different manner. The Court has interpreted the requirement to refer to the content of commercial speech that is unambiguously disseminated within the public communicative sphere, as for example within newspaper advertisements. ${ }^{177}$ Used in this way, the misleading requirement does not refer to the structural relationship between a speaker and her audience, but to the meaning of a speaker's words. ${ }^{178}$ The requirement strips of First Amendment protection speech that, while not outright false, carries the potential to deceive its audience. ${ }^{179}$ This usage of the mis-

173. MEIKLEJOHN, supra note 53, at 25.

174. See supra text accompanying notes $92-98$.

175. Edenfield v. Fane, 507 U.S. 761, 774-75 (1993); Ohralik v. Ohio State Bar Ass'n, 436 U.S. 447, 465 (1978); supra notes $104-108$ and accompanying text.

176. Zauderer v. Office of Disciplinary Counsel, 471 U.S. 626, 642 (1985); see Shapero v. Ky. Bar Ass'n, 486 U.S. 466, 475 (1988) ("In assessing the potential for overreaching and undue influence, the mode of communication makes all the difference.").

177. See, e.g., Zauderer, 471 U.S. at 652-53.

178. Hence the Court stated in In re R.M.J. that the First Amendment would not protect commercial speech when its "particular content or method ... suggests that it is inherently misleading." In re R.M.J., 455 U.S. 191, 203 (1982) (emphasis added).

179. It should be said about this usage of the misleading requirement that, although the Court has been careful not to impugn administrative authority to review commercial speech for deceptive 
leading requirement is controversial, ${ }^{180}$ but nevertheless enormously significant, for it authorizes a "vast regulatory apparatus in both the federal government and the states... to control ... potentially misleading or deceptive speech." ${ }^{\prime 81}$

It is all the more important, therefore, fully to grasp the deep incompatibility between this interpretation of the misleading requirement and the Meiklejohnian justifications for First Amendment protection of commercial speech. "Just so far as ... the citizens who are to decide an issue are denied acquaintance with information or opinion or doubt or disbelief or criticism which is relevant to that issue," Meiklejohn writes, "just so far the result must be ill-considered, ill-balanced planning for the general good. It is that mutilation of the thinking process of the community against which the First Amendment to the Constitution is directed." ${ }^{182}$ When the Central Hudson misleading requirement is used to censor the content of speech, it invites the state to mutilate the thinking process of the community by censoring communication that the state believes might potentially be deceptive.

To analyze this issue, we must more precisely specify what it means to label speech as misleading. If a health reformer were to publish an essay concluding that "eggs are healthy,"183 the assertion would without doubt be viewed as part of public discourse and protected as a hypothesis, an idea that cannot be sanctioned by the state as false. But if a commercial group, the National Commission on Egg Nutrition, were to assert precisely the same proposition,

meanings, see Zauderer, 471 U.S. at 645 , it has itself been quite chary of using the Central Hudson misleading requirement to deprive commercial speech of constitutional protection on the grounds of its content. Early in the career of the doctrine, the Court found the use of a trade name that had "no intrinsic meaning" to be deceptive, Friedman v. Rogers, 440 U.S. 1, 12-13, (1979), and it later authorized compelled disclosures in order to avoid "the possibility of deception." Zauderer, 471 U.S. at 652 . But for the most part the Court has been unsympathetic to claims that commercial speech is misleading, rejecting "'mere speculation or conjecture"' and insisting that "the State 'must demonstrate that the harms it recites are real."' lbanez v. Fla. Dep't of Bus. \& Profl Regulation, 512 U.S. 141, 143 (1994) (quoting Edenfield, 507 U.S. at 770-71).

180. In Peel v. Attomey Registration \& Disciplinary Commission, 496 U.S. 91 (1990), the Court fractured over the issue of deceptive advertising, with the decisive votes of Justices Thurgood Marshall and Brennan standing for the conclusion that "States may prohibit actually or inherently misleading speech entirely.... The Court has upheld such a ban only when the particular method by which the information is imparted to consumers is inherently conducive to deception and coercion." Id. at 111-12 (Marshall, J., concurring) (citations omitted). Citing Ohralik, Marshall and Brennan would seem to advocate restricting the "misleading" requirement to circumstances where the relationship between a speaker and her audience does not meet the prerequisites of a public communicative sphere. They seem to argue that within the public communicative sphere the state cannot ban commercial speech outright, but only craft regulations designed "to ensure that the information is presented in a nonmisleading manner." Id. at 111.

181. Sullivan, supra note 3, at 153.

182. MEIKLEJOHN, supra note 53 , at 27.

183. This hypothetical is based upon National Commission on Egg Nutrition v. FTC, 570 F.2d 157 (7th Cir. 1977), and the discussion of the case in Kozinski \& Banner, supra note 3, at 642-43. 
the statement might very well be branded as misleading and hence stripped of First Amendment protection under Central Hudson. It would be feared that consumers might interpret the statement as a simple and inaccurate factual claim.

In the case of the health reformer, the focus of analysis is on the speaker. The distinction between "ideas" and "factual statements" is interpreted so as to maximize the speaker's freedom of participation within public discourse. ${ }^{184}$ In the case of the National Commission on Egg Nutrition, by contrast, the focus of analysis is on the audience. The Commission's speech is entirely circumscribed by the danger that its audience might possibly misinterpret its words. These discrepant foci of analysis are roughly what one would expect from the distinct orientations of the participatory and Meiklejohnian models of self-governance.

The Meiklejohnian model, however, requires us to imagine the audience for protected speech as analogous to citizens at a town meeting. Meiklejohn would have us safeguard the flow of information to the "free and equal" persons "who must pass judgment upon unwisdom and unfairness and danger." ${ }^{185}$ But when used to regulate the content of expression, the misleading requirement does not imagine the audience of commercial speech as independent and self-governing in these ways. Instead, as Kathleen Sullivan has perceptively noted, "the consumer is not expected to have the competence or access to information needed to question the advertiser's claim, and the correction is not to be left to competitors and mere government counterspeech." ${ }^{186}$ The Court has frankly acknowledged that the misleading requirement is premised on the notion that "the public lacks sophistication." "187

This is why the Central Hudson misleading requirement, when used to prohibit commercial speech based upon the content of that speech, is incompatible with the Meiklejohnian premises that justify protecting commetcial speech. ${ }^{188}$ Incompatibility exists to the extent that the Court interprets the

184. See, e.g., Time, Inc. v. Pape, 401 U.S. 279, 290 (1971) (distinguishing between interpretations and factual assertions).

185. MEIKLEJOHN, supra note 53, at 25, 27.

I86. Sullivan, supra note 3, at 156; see United States v. Articles of Drugs, 263 F. Supp. 212, 215 (D. Neb. 1967).

187. In re R.M.J., 455 U.S. 191, 200 (1982) (quoting Bates v. State Bar of Ariz., 433 U.S. 350, 383 (1977)). But see Peel v. Attorney Registration \& Disciplinary Comm'n, 496 U.S. 91, 105 (1990) (Stevens, J., plurality opinion) ("We reject the paternalistic assumption that the recipients of petitioner's letterhead are no more discriminating than the audience for children's television.").

188. Notice that this tension does not extend to the Court's rule that commercial speech that is only "potentially misleading" may be required to be supplemented by compelled disclosures so as to offer more complete and accurate information. See R.M.J., 455 U.S. at 203. Supplementation of speech is consistent with a Meiklejohnian model, because it increases the information available to democratic decision makers. 
category of misleading speech more expansively than the category of false factual statements, which can be regulated consistently with a Meiklejohnian model. And this discrepancy can be precisely measured by the Court's willingness to attribute to consumers an inadequate ability to interpret and evaluate ambiguous information. Such attribution suggests that the Court has not been able entirely to transcend older images of consumers as vulnerable and reliant, images that underlay the Court's earlier refusal to extend any First Amendment protection to commercial speech. ${ }^{189}$

For this reason, Central Hudson's use of the misleading requirement as a threshold precondition for First Amendment protection cannot, without internal contradiction, be premised upon the content of speech. The contradiction can be resolved only by redefining the misleading requirement to focus on the specific conditions that might be understood to render consumers dependent and vulnerable. The Court might conclude, for example, that state protections are necessary when the evaluation of commercial information requires unusual expertise ${ }^{190}$ or when there are reasons to doubt the autonomy of consumers. ${ }^{191}$ Such an approach would shift judicial attention away from the content of particular communications and instead direct judicial scrutiny to the structural preconditions of consumer rationality and independence.

This approach would essentially align the Central Hudson misleading requirement with the first interpretation we have discussed. lt would use the requirement to determine the boundaries of a public communicative sphere. lt would not define these boundaries exclusively in terms of "the particular method by which ... information is imparted to consumers," ${ }^{192}$ but would instead invite the Court to offer a more discriminating and nuanced account of the circumstances under which consumers are constitutionally to be regarded as free and equal citizens. The implication of such an approach, however, is that it would be unconstitutional for the state to suppress the content of commercial speech as misleading in structural conditions where consumers are deemed to be independent and competent. ${ }^{193}$

189. Justice William $\mathrm{H}$. Rehnquist saw this very clearly when, objecting to the very creation of commercial speech doctrine, he argued that consumers, unlike citizens, cannot be trusted to know their own interests. See Cent. Hudson Gas \& Elec. Corp. v. Pub. Serv. Comm'n, 447 U.S. 557,593 n.5 (1980) (Rehnquist, J., dissenting).

190. See, e.g., R.M.J., 455 U.S. at 200. 1 owe to Eugene Volokh the suggestion that the Court might even regard consumers as vulnerable when an adequate understanding of commercial speech would require more time and resources than the average consumer could reasonably be asked to invest.

191. See, e.g., Sylvia A. Law, Addiction, Automomy, and Advertising, 77 low A L. REV. 909 (1992).

192. Peel, 496 U.S. at 112 (Marshall, J., concurring).

193. Outright fraud would remain subject to legal control, because falsity remains an element of the tort. See Soules v. Gen. Motors Corp., 402 N.E.2d 599, 601 (Ill. 1980). 


\section{First Amendment Protections}

Once the threshold conditions of the Central Hudson test are satisfied, its remaining three prongs articulate the First Amendment safeguards to which commercial speech is entitled. These safeguards are astonishingly abstract. To survive First Amendment review, the state need only craft regulations that directly advance a substantial interest in a manner that is not too overinclusive; that is, in a manner "whose scope is 'in proportion to the interest served."'194

The bland, generic quality of these requirements is unconnected to any particular First Amendment theory, which is no doubt why they have proved susceptible to such wide swings of application. In 1986, Justice Rehnquist was able to convince the Court to apply the test in so deferential a manner as to virtually strip commercial speech of all constitutional protection. ${ }^{195}$ But recently the Central $\mathrm{Hudson}$ test has been applied with a severity that borders on strict scrutiny. ${ }^{196}$ These extraordinary oscillations exemplify the essential difficulty of contemporary commercial speech doctrine, which is that its major doctrinal test remains untethered to any particular First Amendment theory.

Doctrine fulfills its function when it accurately accomplishes the purposes of the law. If 1 am correct that the purpose of protecting commercial speech is to realize the constitutional values articulated in a Meiklejohnian vision of democratic self-government, then commercial speech doctrine ought to articulate and apply those values. Although the specific doctrinal rules applied to commercial speech regarding compelled disclosure, overbreadth, and prior restraints, do roughly express the implications of a

194. Bd. of Trs. v. Fox, 492 U.S. 469, 480 (1989) (quoting R.M.J., 455 U.S. at 203).

195. See Posadas de P.R. Assocs. v. Tourism Co., 478 U.S. 328 (1986). Justice Rehnquist had previously and conspicuously taken the position that commercial speech doctrine was a mistake, and that commercial speech should not receive any constitutional protection. See Cent. Hudson Gas \& Elec. Corp. v. Pub. Serv. Comm'n, 447 U.S., 557, 588-99 (1980) (Rehnquist, J., dissenting in part); Bates v. State Bar of Ariz., 433 U.S. 350, 404 (1977) (Rehnquist, J., dissenting); Va. State Bd. of Pharmacy v. Va. Consumer Council, lnc., 425 U.S. 748, 781-90 (1976) (Rehnquist, J., dissenting). In Posadas he crafted an opinion that in effect achieved this same result. He argued that "it is precisely because the government could have enacted a wholesale prohibition of the underlying conduct that it is permissible for the government to take the less intrusive step of allowing the conduct, but reducing the demand through restrictions on advertising." Posadas, 478 U.S. at 346 . By concluding that the power to regulate conduct necessarily implied the power to regulate commercial speech that advertised the conduct, Rehnquist effectively reduced First Amendment protections of commercial speech to the due process safeguards for the conduct the commercial speech sought to advertise. It is remarkable that after a decade of commercial speech decisions, Rehnquist was able to assemble a Court for this approach.

196. See 44 Liquormart, lnc. v. Rhode lsland, 517 U.S. 484, 528 (1996) (O’Connor, J., concurring); Sullivan, supra note 3, at 141-45. 
Meiklejohnian vision, the Central Hudson test does not. As a consequence, important aspects of the doctrine have been left to twist slowly in the wind.

The relationship of First Amendment doctrine to constitutional objectives ought to be assessed in two distinct dimensions. The first is that of government purpose. A useful doctrine ought to distinguish government interests that are compatible with relevant constitutional values from those that are not. The second is that of impact. A useful doctrine ought to distinguish effects on speech that are compatible with relevant constitutional values from those that are not.

\section{a. The Central Hudson Test and the Purpose of Government Regulations}

The Central Hudson test asks whether government interests in regulating commercial speech are substantial. We can read this as a rough way of saying that the informational function of commercial speech ought to be compromised only if there is a pretty good reason to do so. This may be an acceptable starting point for analysis, but doctrine ought to do more. It ought to ask whether government purposes are consistent or inconsistent with pertinent constitutional values. The Central Hudson test pointedly avoids this inquiry.

A careful elaboration of a Meiklejohnian perspective, however, would rule out certain government purposes as prima facie inappropriate. It should be regarded as improper for the government to regulate commercial speech in order to affect governmental decision making. A prohibition on advertisements of Nazi memorabilia, for example, should be prima facie unacceptable if enacted for the purpose of preventing persons from voting in ways influenced by Nazi ideas. ${ }^{197}$ For similar reasons, it should be regarded as presumptively improper for the government to regulate commercial speech in order to influence the formation of public opinion with regard to particular conceptions of national identity ${ }^{198}$ A prohibition on advertisements of attractive cars, for example, should be unacceptable if enacted for the purpose of manipulating public opinion in favor of mass transportation.

Typically, however, the government does not prohibit advertising in order to influence political decision making or public opinion, but instead to

197. In the end, of course, we might permit the government to advance inappropriate purposes, if the stakes in doing so were sufficiently high. It is not the function of doctrine to place the state in a suicidal straitjacket, but instead to identify the particular circumstances in which the state must meet very high thresholds of justification, akin to strict scrutiny, before it can act.

198. For a fuller development of this point, see Post, Meiklejohn's Mistake, supra note 25, at 1116-17. 
regulate consumer behavior. A government will ban "for sale" signs to discourage home sales so as to preserve racially integrated neighborhoods under threat of blockbusting, ${ }^{199}$ or it will bar energy advertisements in order to promote conservation, ${ }^{200}$ or it will proscribe casino or liquor advertisements in order to ameliorate the evils of gambling or drinking. ${ }^{201}$ ln recent years, these forms of regulation have become deeply controversial, so much so that they threaten to unravel the Central Hudson test itself.

Justice Blackmun in fact dissented from Central Hudson because he believed that it should be presumptively improper for the state to attempt to modify behavior by suppressing truthful commercial information. $\mathrm{He}$ argued that "a strict standard of review" should apply "to suppression of commercial information, where the purpose of the restraint is to influence behavior by depriving citizens of information." ${ }^{202}$ Subsequently Justice Clarence Thomas has written forcefully that the Central Hudson test ought not to be applied to situations in which "the asserted interest is one that is to be achieved through keeping would-be recipients of the speech in the dark." ${ }^{203}$ And Justice John Paul Stevens has also argued strongly against the Central Hudson test, because "[t]he First Amendment directs us to be especially skeptical of regulations that seek to keep people in the dark for what the government perceives to be their own good."204

There are (at least) three distinct reasons for this growing opposition to state suppression of truthful advertising in order to modify behavior. These are (1) ambiguity concerning the purpose of commercial speech doctrine, (2) the conflation of commercial speech and public discourse, and (3) hostility to paternalism. Each of these reasons contributes to the centrifugal pressure currently tearing at the fabric of commercial speech doctrine.

199. See Linmark Assocs., Inc. v. Township of Willingboro, 431 U.S. 85, 96-97 (1977).

200. See Cent. Hudson, 447 U.S. at 568.

201. See, e.g., Posadas de P.R. Assocs. v. Tourism Co., 478 U.S. 328 (1986); 44 Liquormart, 517 U.S. 484.

202. Cent. Hudson, 447 U.S. at 577 (Blackmun, J., concurring).

203. 44 Liquormart, 517 U.S. at 523 (Thomas, J., concurring). In Greater New Orleans Broadcasting Ass' $n v$. United States, Justice Thomas concurred specially to reiterate his view that "In cases such as this, in which the government's asserted interest is to keep legal users of a product or service ignorant in order to manipulate their choices in the marketplace," the Central Hudson test should not be applied because "such an 'interest' is per se illegitimate and can no more justify regulation of 'commercial' speech than it can justify regulation of 'noncommercial' speech." Greater New Orleans Broad. Ass'n v. United States, 527 U.S. 173, 197 (1999) (quoting 44 Liquormart, 517 U.S. at 518 (Thomas, J. concurring)). Justice Thomas, however, has joined the Court in suppressing commercial speech for reasons other than keeping consumers "in the dark." See, e.g., Fla. Bar v. Went For It, Inc., 515 U.S. 618 (1995).

204. 44 Liquormart, 517 U.S. at 503 (Stevens, J., plurality opinion) (joined by Kennedy, J. and Ginsburg, J.). 


\section{Ambiguity About the Purpose of Commercial Speech Doctrine}

Opposition to the suppression of truthful advertising to modify consumer behavior may express judicial uncertainty about the constitutional purpose of commercial speech doctrine. If that purpose were to protect market efficiency, government efforts to shape consumer preferences by suppressing accurate information about legal goods and services would be presumptively improper. Such efforts would violate an independent First Amendment ideal of consumer autonomy, conceptualized as the right of each consumer to receive pertinent and truthful information about market choices. One hypothesis, therefore, is that current dissatisfaction with Central Hudson reflects a resurgent commitment to Blackmun's original claim that commercial speech doctrine serves the constitutional purpose of ensuring "the proper allocation of resources in a free enterprise system."

This account is most plausible with regard to Justice Thomas, because he has expressed particular approval of Blackmun's claim, ${ }^{206}$ while at the same time joining controversial opinions approving the suppression of commercial speech to serve government goals ostensibly consistent with market efficiency, like maintaining the reputation of the bar. ${ }^{207}$ Justice Stevens's background and expertise in antitrust has also seemed to endow him with an intense appreciation of the centrality and significance of market institutions. ${ }^{208}$

Nevertheless, the Court has never squarely and unambiguously embraced consumer autonomy and the free market as independent First Amendment ideals. If recent controversy over the Central Hudson test signifies that the Court is now ready to reshape First Amendment doctrine to reflect a constitutional commitment to market efficiency and consumer sovereignty, it would be best to have a full and candid assessment of that ambition. ${ }^{209}$ As 1 have already suggested, I myself believe that the First Amendment should no more

205. Va. State Bd. of Pharmacy v. Va. Consumer Council, Inc., 425 U.S. 748, 765 (1976).

206. See Glickman v. Wileman Bros. \& Elliot, Inc., 521 U.S. 457, 505 n.3 (1997) (Thomas, J, dissenting) (implying that there is a similarity between the First Amendment and the philosopby of Herbert Spencer); Rubin v. Coors Brewing Co., 514 U.S. 476, 481-82 (1995).

207. See Went For lt, Inc., 525 U.S. at 635.

208. See, e.g., Daniel Farber, The Scholarly Attorney as Lawyerly Judge: Stevens on Statutes, 1992-1993 ANN. SURV. AM. L. xxxv, xxxvi-xxxvii.

209. For a good discussion tending toward this line, see Halberstam, supra note 6 . Halberstam views commercial speech doctrine as protecting the social norms implicit in commercial transactions. He seems to assume that the First Amendment incorporates and enforces the norms of any "bounded speech practice." Id. at 832-33. While I completely agree that these norms affect the constitutional values that First Amendment jurisprudence is willing to locate in particular speech practices, and therefore that these norms are highly material to locating the boundaries of public discourse, it is not clear to me that the First Amendment necessarily accepts these norms as themselves meriting constitutional protection. That case has yet to be made. 
be interpreted to incorporate Milton Friedman than the Fourteenth Amendment should be read to incorporate Herbert Spencer. ${ }^{210}$

\section{The Conflation of Commercial Speech and Public Discourse}

A second source of contemporary opposition to the suppression of truthful advertising to modify consumer behavior is the conflation of commercial speech and public discourse. Within public discourse it is presumptively improper to prohibit speech because it might be persuasive. In its early decisions, the Court was prone simply to apply to commercial speech First Amendment principles developed for the protection of public discourse. ${ }^{211}$ Prohibitions of truthful advertisements might thus seem especially suspect because they are designed precisely to counteract the persuasive power of speech. ${ }^{212}$

Justice Stevens has come close to explicitly defending this perspective. Because of his growing dismay at "the artificiality of a rigid commercial/noncommercial distinction," ${ }^{213}$ Stevens has sought to restructure commercial speech doctrine to focus on the particular government interests that justify differential treatment of commercial speech. He has argued that "[i]t is the State's interest in protecting consumers from 'commercial harms' that provides 'the typical reason why commercial speech can be subject to greater governmental regulation than noncommercial speech." 214

Justice Stevens has accordingly advanced a theory in which commercial speech receives the same high degree of protection as public discourse, subject only to the state's specific interests in averting commercial harms that might justify more intrusive regulation of commercial speech.

When a State regulates commercial messages to protect consumers from misleading, deceptive, or aggressive sales practices, or requires the disclosure of beneficial consumer information, the purpose of its regulation is consistent with the reasons for according constitutional

210. See Coll. Savs. Bank v. Fla. Prepaid Postsecondary Educ. Expense Bd., 527 U.S. 666, 691 (1999) ("We had always thought that the distinctive feature of Lochner, nicely captured in Justice Holmes's dissenting remark about 'Mr. Herbert Spencer's Social Statics,' was that it sought to impose a particular economic philosophy upon the Constitution." (citations omitted)).

211. See, e.g., Linmark Assocs., lnc. v. Township of Willingboro, 431 U.S. 85 (1977).

212. See id. at 94, 96-97. This theme is explicit in Justice Stevens's early opinions. See, e.g., Cent. Hudson Gas \& Elec. Corp. v. Pub. Serv. Comm'n, 447 U.S. 557, 581-82 (1980) (Stevens, J., concurring).

213. Rubin v. Coors Brewing Co., 514 U.S. 476, 494 (1995) (Stevens, J., concurring).

214. 44 Liquormart, 1nc. v. Rhode 1sland, 517 U.S. 484, 502 (1996) (Stevens, J., plurality opinion) (joined by Kennedy, J. and Ginsburg, J.) (quoting Cincinnati v. Discovery Network, Inc., 507 U.S. 410, 426 (1993)). For a good example of academic perturbation at this position, see Van Alstyne, supra note 9, at 1638-48. 
protection to commercial speech and therefore justifies less than strict review. However, when a State entirely prohibits the dissemination of truthful, nonmisleading commercial messages for reasons unrelated to the preservation of a fair bargaining process, there is far less reason to depart from the rigorous review that the First Amendment generally demands. ${ }^{215}$

This passage fundamentally challenges the entire conceptual structure of Central Hudson, which conceives commercial speech as a discrete category of communication that can be regulated for a wide variety of reasons. Stevens, by contrast, denies that there is a categorical distinction between commercial speech and public discourse. He therefore claims that the First Amendment should apply to commercial speech the protections applicable to public discourse, unless the government can adduce interests specifically applicable to commercial speech, like "the preservation of a fair bargaining process," which justify diminishing these protections. ${ }^{216}$ If Stevens's premises are accepted, prohibiting advertisements to modify consumer behavior would violate the First Amendment, because such prohibitions would not seek to redress specifically commercial harms and because such prohibitions would be per se unconstitutional if applied to public discourse.

There is good reason, however, to reject Stevens's premises. Stevens accepts as a baseline for constitutional protection for speech a certain kind of "rigorous review that the First Amendment generally demands," and he believes that variations from this baseline should occur only as required by the pressing necessities of distinct government interests. But Stevens never inquires how this baseline of "rigorous review" has itself been determined. If that baseline was actually developed to protect a specific constitutional communicative function, rather than "speech as such," it would be inappropriate to apply it to expression not serving that function. Stevens never pursues this inquiry, however, because he implicitly assumes that all speech serves

215. 44 Liquormart, 517 U.S. at 501. "There is ... no question," Stevens writes, that a ban on liquor advertising in order to reduce the consumption of alcohol "serves an end unrelated to consumer protection. Accordingly, we must review the price advertising ban with 'special care,' mindful that speech prohibitions of this type rarely survive constitutional review." Id. at 504 (quoting Cent. Hudson, 447 U.S. at 566 n.9).

216. Although Stevens does refer to "the reasons for according constitutional protection to commercial speech," thereby implying that commercial speech might receive a distinct kind of First Amendment protection, in contrast to the state having distinct and pressing reasons to regulate commercial speech, he never inquires into the nature of these reasons or inquires whether they might be different from those that justify "the rigorous review that the First Amendment generally demands." The upshot is that in the absence of state interests specifically justifying the regulation of commercial speech, Stevens assumes throughout his opinion that commercial speech ought to receive the same "rigorous" protection as public discourse. 44 Liquormart, 517 U.S. at 501. 
the same constitutional function and hence that all speech should be subject to the same rigorous baseline of protection.

But this assumption is manifestly false, as we have already seen in our comparison of the Ohralik and Primus decisions. ${ }^{217}$ Although the state's interests in protecting clients from the potential harms of in-person legal solicitation were identical in each case, the Court nevertheless employed radically different constitutional standards, depending upon whether it understood public discourse or commercial speech to be at stake. The stark discrepancy of constitutional method can be explained only by the distinct constitutional values of public discourse and commercial speech.

There are many other examples of this same phenomenon. The government has specific interests in managing its employees, including the speech of its employees. These interests do not change if employee speech happens to be about a matter of public concern, yet constitutional protections for employee speech do change, because speech about matters of public concern embodies a distinct and greater constitutional value. ${ }^{218}$ For analogous reasons, constitutional protections for defamation will vary depending upon whether or not defamation is about a matter of public concern, although government interests in protecting reputation remain constant. ${ }^{219}$

Even Justice Stevens has recognized that different constitutional values are immanent in different kinds of speech. In his recent opinion in Glickman ข. Wileman Brothers $\mathscr{B}$ Elliott, Inc. ${ }^{220}$ for example, Stevens writes that compelling persons to engage in "political" or "ideological" speech imperils entirely different constitutional concerns than compelling persons to engage in mere commercial speech. ${ }^{221}$ The former threatens fundamental First Amendment interests of individual autonomy not present in the latter.

It is evident, then, that constitutional protections depend not only upon the nature of government interests, but also upon the constitutional significance of the speech that is regulated. The distinction between commercial speech and public discourse is meant to mark precisely such a difference in the constitutional value of communication. The distinction is no doubt difficult and at points obscure, but its central thrust is to separate speech that is constitutionally valued because it is itself a way of participating in the processes of democratic self-governance, from speech that is constitu-

217. For a discussion, see supra text accompanying notes 130-134.

218. See Connick v. Myers, 461 U.S. 138, 145-54 (1983).

219. Compare Gertz v. Robert Welch, lnc., 418 U.S. 323 (1974), with Dun \& Bradstreet, Inc. v. Greenmoss Builders, Inc., 472 U.S. 749 (1985).

220. 521 U.S. 457 (1997).

221. Id. at 469-72. 
tionally valued merely because within a public communicative sphere it provides information relevant for democratic self-government.

This difference of constitutional value makes it dangerous to analyze issues of commercial speech by uncritically relying upon First Amendment intuitions developed in the arena of public discourse. ${ }^{222}$ The reason why the First Amendment prohibits the state from suppressing public discourse on the grounds of its persuasiveness is that participation within democratic selfgovernance is understood to encompass a variety of social relationships, ranging from dialogue to association to persuasion. Within public discourse, speakers seek to persuade others of their point of view and in this way to make the state responsive to their perspective; for the state deliberately to disrupt this communicative relationship is to negate the vety constitutional raison d'être of public discourse.

This analysis, however, is not applicable to commercial speech, which is protected to ensure "the free flow of information and ideas." ${ }^{223}$ Thus when the Court holds that the government can compel commercial speech, it presumes that the state can diminish a speaker's persuasiveness in order to facilitate the dissemination of accurate information. The doctrine is explicable because the only social relationships that matter from a Meiklejohnian perspective are those connected to the uptake and use of information by citizens in democratic decision making. The interests of speakers in persuading others to action are not of particular constitutional moment. ${ }^{224}$

This implies that in analyzing statutes suppressing accurate commercial advertising, government purposes should be assessed on their own merits. Government interests in promoting racial integration or energy conservation

222. I have argued elsewhere, for example, that the distinction between content-neutral and content-based regulations is best interpreted as expressing understandings of specific government purposes deemed impermissible within public discourse. See Post, supra note 37, at 1277-79. It is therefore of no small significance that the distinction has virtually no application within the domain of commercial speech, where most regulation is content based. See, e.g., Bolger v. Youngs Drug Prods. Corp., 463 U.S. 60, 65 (1983).

223. Cincinnati v. Discovery Network, Inc., 507 U.S. 410, 426 n.21 (1993).

224. We thus often regulate communication outside of public discourse for fear that it might be persuasive. We restrict the speech of physicians, for example, for fear that they might cause their patients to undergo medical treatments inconsistent with generally accepted medical practice. See, e.g., Molien v. Kaiser Found. Hosp., 616 P.2d 813 (Cal. 1980). We restrict the speech of persons who would persuade others to break their contracts, for fear that their speech might undermine important social policies promoting the stability and reliability of contractual undertakings. See, e.g., Quelimane Co. v. Stewart Title Guar. Co., 960 P.2d 513, 530 (Cal. 1998). We restrict the speech of soldiers who would contest the orders of their superiors, for fear that their speech might persuade others to mutiny. See, e.g., Greer v. Spock, 424 U.S. 828, 840 (1976); Parker v. Levy, 417 U.S. 733, 759 (1974). These examples suggest that constitutional protection for the "persuasive" power of speech does not automatically apply outside the boundaries of public discourse, and that such protection depends very much upon specific social contexts. See CASS R. SUNSTEIN, DEMOCRACY AND THE PROBLEM OF FREE SPEECH 176 (1995). 
have their own weight and validity. They should not be automatically and reflexively dismissed because of a speaker's interests in being persuasive.

\section{Opposition to Paternalism}

State efforts to advance legitimate interests through the suppression of accurate information, however, have aroused the suspicion of an increasing number of Justices. Insofar as this suspicion focuses on the constitutionality of government purposes, and insofar as it can be distinguished from a First Amendment commitment to market efficiency or from a conflation of public discourse with commercial speech, this suspicion seems to derive from a hostility to paternalism that has been most explicitly articulated by Justice Stevens:

Any "interest" in restricting the flow of accurate information because of the perceived danger of that knowledge is anathema to the First Amendment; more speech and a better informed citizenry are among the central goals of the Free Speech Clause. Accordingly, the Constitution is most skeptical of supposed state interests that seek to keep people in the dark for what the government believes to be their own good. One of the vagaries of the "commercial speech" doctrine in its current form is that the Court sometimes takes such paternalistic motives seriously. ${ }^{225}$

This is a powerful passage, whose perspective seems to be gaining ground within the Court. To appreciate its reach and force, we must distinguish between government efforts to alter public opinion by means of suppressing advertising and government efforts to modify behavior by means of suppressing the information contained in commercial speech. The paradigmatic instances of this distinction are plain enough. We might contrast, for example, a statute designed to inhibit public approbation of violence that prohibits positive depictions of brutality in advertisements, with a statute designed to discourage neighborhood gentrification that suppresses price information in real estate advertisements. No doubt a good many difficult and obscure cases will lie between these paradigmatic examples.

As we have already observed, the Meiklejohnian justifications for commercial speech doctrine would render prima facie suspect government efforts to alter public opinion by means of suppressing advertising. ${ }^{226}$ Stevens's condemnation of paternalism, however, aspires to transcend this distinction and to condemn as constitutionally improper even government efforts to modify

225. Rubin v. Coors Brewing Co., 514 U.S. 476, 497 (1995) (Stevens, J., concurring) (citation omitted).

226. See supra note 198 and accompanying text. 
behavior by means of suppressing the information contained in commercial speech. Stevens views such efforts as attempts "to keep people in the dark for what the government believes to be their own good," and he charges that "such paternalistic motives" are not be taken "seriously."227

But the distinction we have just noted implies that government "motives" in suppressing accurate commercial information need not be different from those that impel most ordinary legislation. In Linmark Associates, Inc. v. Township of Willingboro, ${ }^{228}$ for example, the government forbade "for sale" signs in order to prevent the blockbusting of a racially integrated neighborhood. ${ }^{229}$ The regulation had nothing to do with the "good" of individual buyers or sellers, but was instead enacted to preserve the possibility of integrating housing. The ordinance was not paternalistic, at least as Stevens seems to be defining the term. It did not regulate the behavior of individuals in order to protect them from themselves; it sought instead to achieve a public good.

Similarly, when the government in Central Hudson prohibited energy advertising to promote energy conservation, it was not for "the good of" individual consumers, but instead aimed at the preservation of valuable nonrenewable resources. ${ }^{230}$ A government effort to attain this very same end by flatly prohibiting certain energy uses would not be dismissed as paternalistic. Its purposes and motives would no doubt be taken quite seriously.

This suggests that the charge of paternalism is actually something of a red herring. As Daniel Hays Lowenstein has observed, "it is simply not the case that the commercial speech doctrine has been deployed against paternalistic state measures. It would be far closer to the truth to say that restrictions on commercial speech are usually struck down unless they are intended to serve genuinely paternalistic purposes. ${ }^{231}$ Certainly our analysis of the misleading requirement would support Lowenstein's conclusion, for the Court has used this requirement to prohibit the circulation of information on the blatantly paternalistic assumption that consumers are unable properly to interpret commercial speech for themselves.

227. Coors Brewing Co., 514 U.S. at 497. Part IV of Stevens's opinion in 44 Liquormart gestures toward Stevens's arguments against paternalism. See 44 Liquormart, Inc. v. Rhode Island, 517 U.S. 484, 501-04 (1996) (Stevens, J., plurality opinion) (joined by Kennedy, J. and Ginsburg, J.). These arguments are, however, most fully and forcefully developed in Stevens's opinion for himself alone in Coors Brewing Co., 514 U.S. at 491-98.

228. 431 U.S. 85, 57-91 (1997).

229. See id. at 87-91.

230. Cent. Hudson Gas \& Elec. Corp. v. Pub. Serv. Comm'n, 447 U.S. 557, 568 (1980).

231. Daniel Hays Lowenstein, "Too Much Puff": Persuasion, Patemalism, and Commercial Speech, 56 U. CIN. L. REV. 1205, 1238 (1988). 
If there is nothing constitutionally suspicious about government efforts to conserve energy or to integrate housing, Stevens's discomfort with these regulations must ultimately stem from the means by which the government has attempted to achieve these otherwise legitimate purposes. In the end, Stevens's argument turns on a fierce opposition to state regulations that seek to ameliorate social problems by curtailing information rather than by regulating behavior directly. By employing these means, Stevens suggests, the state directly infringes First Amendment interests in "more speech and a better informed citizenry."

These are certainly important interests, and they do evoke images of independent citizens deciding for themselves how to use information. But these interests are ruptured every time the government uses confidentiality as a means to an end. Every confidentiality requirement suppresses the flow of accurate information to citizens because of fear that persons will use or respond to the information in a manner that might cause harm. They thus compromise the autonomy of persons to receive and to act upon information.

Most states, for example, impose confidentiality requirements on grand jury proceedings. These requirements prohibit a willing speaker from communicating with a willing audience. They do so in part in order to optimize the performance of grand juries, because it is believed that their function would be impaired were the flow of accurate information to citizens not restricted. Yet grand jury confidentiality requirements are regarded as neither paternalistic nor as anathema to the First Amendment. ${ }^{232}$ Nor is it regarded as anathema when the federal government seeks to avert dangers to the national security by prohibiting the dissemination of accurate information that is classified or that concerns atomic weapons. ${ }^{233}$ Dangers to privacy norms are averted by suppressing the circulation of medical records. ${ }^{234}$ Dangers to a well-functioning economy are averted by prohibiting the disclosure of trade secrets. ${ }^{235}$

Each of these regulations compromises the autonomy of persons to receive and act upon information. Each poses serious First Amendment issues that

232. See, e.g., FED. R. CRIM. P. 6(e)(2); Douglas Oil Co. v. Petrol Stops Northwest, 441 U.S. 211, 218-19 (1979) ("We consistently have recognized that the proper functioning of our grand jury system depends upon the secrecy of grand jury proceedings.").

233. See, e.g., 18 U.S.C. \$ 798 (1994); 42 U.S.C. \& 2274 (1994); United States v. Boyce, 594 F.2d 1246, 1252 (9th Cir. 1979); United States v. Progressive, lnc., 467 F. Supp. 990,994 (W.D. Wis. 1979).

234. See, e.g., CAL. CIV. CODE $\$ 56.10$ (West $1982 \&$ Supp. 2000); Pettus v. Cole, 49 Cal. App. 4th 402 (1996). For a recent example of the Court upholding restrictions on the disclosure of information in order to sustain privacy values, see Reno v. Condon, 120 S. Ct. 666, 671 (2000).

235. See, e.g., CAL. CIV. CODE \& 3426 (West 1997); E.l. duPont deNemours \& Co. v. Christopher, 431 F.2d 1012 (5th Cir. 1970); Bridge Publ'ns, lnc. v. Vien, 827 F. Supp. 629, 63233 (S.D. Cal. 1993). 
must be resolved by weighing the relevant state objective against the First Amendment value of the prohibited speech. ${ }^{236}$. In none of these situations would analysis be assisted by abstract charges of paternalism, or by generic appeals to the need for "more speech and a better informed citizenry." Instead, the strength and quality of the government's interest, its instrumental connection to the suppression of speech, the constitutional value of the speech, and the practical availability of alternative modes of regulation, would all require careful review.

In the particular environment of commercial speech, the justifications for First Amendment protection do not suggest that government efforts either to constrict consumer autonomy or to undermine the persuasiveness of speakers should render regulation especially suspect. Instead, doctrine ought to assess whether the "informational function" of commercial speech has been unacceptably compromised. Such analysis in fact fits nicely with Justice Stevens's appeal to the need for "a better informed citizenry." This appeal, however, does not imply that state purposes in suppressing accurate information in nonmisleading advertisements to modify consumer behavior need be presumptively improper. ${ }^{237}$ When stripped of its rhetoric of "paternalistic motives," Stevens's analysis actually implies the quite different proposition that the effect of state regulations ought to be carefully monitored to ensure that citizens retain adequate access to accurate and truthful information relevant to democratic decision making.

\section{b. The Central Hudson Test and the Impact of Government Regulation on Commercial Speech ..}

It is in fact surprising that the Central Hudson test refuses explicitly to evaluate the impact of state regulations on the dissemination of information contained in commercial speech. At most the test vaguely disfavors overinclusive statutes. Yet if commercial speech is constitutionally protected because of its informational function, it would certainly seem to follow that commercial speech doctrine ought self-consciously to safeguard this function. The only hint of such an ambition, however, appears in footnote nine of

236. Even within public discourse, moreover, it is not "anathema" to suppress accurate speech because it might cause harm, if the state does so in a content-neutral way. See Post, supra note 37, at $1260-64$. Even within public discourse, that is, the particular interests served by government suppression of speech are of great significance.

237. Of course a state's purpose could be presumptively improper, if, for example, it were to repress truthful nonmisleading advertising merely in order to keep consumers "in the dark." But such a state purpose will no doubt.prove bizarre and rare. In most cases, a state will seek to suppress advertising to serve perfectly acceptable social goals, as, for example, the attainment of energy conservation. 
the Central Hudson opinion, which states: "We review with special care regulations that entirely suppress commercial speech in order to pursue a nonspeech-related policy. In those circumstances, a ban on speech could screen from public view the underlying governmental policy."1238

Although the passage is somewhat obscure, its general thrust seems to me basically right. If commercial speech is constitutionally valuable because it conveys information to facilitate better public decision making, then constitutional analysis ought to assess the impact of government regulations on the circulation of information, using as a standard of assessment the potential effect on public decision making and public opinion. Because any such assessment will no doubt entail considerable guesswork, a workable rule of thumb might well be that government regulations entirely eliminating a category of truthful information are good candidates for heightened constitutional suspicion.

The exact parameters of any such test would no doubt require much careful consideration. The point 1 wish to stress here, however, is that although recent dissatisfaction with the Central Hudson test has focused on the impropriety of government purposes in suppressing truthful advertising, it is possible that this dissatisfaction instead reflects the striking failure of the Central Hudson test to assess how state regulations actually affect the informational function of commercial speech. Justice Stevens, for example, has sought to resuscitate the doctrinal importance of footnote nine of Central Hudsom. ${ }^{239}$ Whether or not the exact formulation of footnote nine is ultimately satisfactory, Stevens seems justified in urging that commercial speech doctrine responsibly express the implications of its own theoretical foundations. The inability of the Central Hudson test carefully to assess the impact of state regulation on the circulation of information constitutes a serious deficiency.

\section{CONCLUSION}

Commercial speech doctrine is now almost a quarter of a century old. Yet in all that time it has never systematically queried its own justifications and implications. By settling quickly and easily into a test whose bland provisions were indifferent to a disciplined account of the constitutional value of commercial speech, the doctrine has allowed fundamental differences of per-

238. Cent. Hudson Gas \& Elec. Corp. v. Pub. Serv. Comm'n, 447 U.S. 557, 566 n.9 (1980).

239. In Part III of his opinion in 44 Liquormart, Inc., Justice Stevens draws heavily on footnote 9 of Central Hudson. See 44 Liquormart, Inc. «. Rhode Island, 5 I7 U.S. 484, $495-500$ (1990) (Stevens, J., plurality opinion) (joined by Kennedy, J., Souter, J., and Ginsburg, J.); Cent. Hudson, 447 U.S. at 566 n.9. 
spective to fester and increase. These differences now threaten to explode the doctrine entirely.

Commercial speech doctrine initially developed on the assumption that commercial speech was constitutionally protected because of its informational function. The pronouncement of the Central Hudson test prematurely stunted the evolution of the doctrine, because the test did not seek to explicate the implications of this function, either in the dimension of government purpose or in the dimension of impact on commercial speech. Nevertheless, the Court also established a structure of rules that persisted alongside of Central Hudson and that clearly sought to express a vision of speech constitutionally valued merely as information.

Contemporary dissatisfaction with the Central Hudson test suggests that this vision is now under considerable pressure. I do not believe that a majority of the Justices will ultimately explicitly embrace market efficiency as an independent First Amendment ideal. Nor do I believe that they will throw aside as paternalistic all confidentiality provisions presently enforced by the law.

My best guess, therefore, is that the commercial speech doctrine will either continue to unfold the implications of its Meiklejohnian foundations by developing the doctrinal tools necessary to assess the impact of state regulation on the actual circulation of commercial information, or it will abandon these foundations as the Justices seek to merge commercial speech with public discourse. At least four Justices of the Court are now edging toward an alternative perspective ${ }^{240}$ in which commercial speech is protected as a kind of public discourse subject to regulations designed to serve specific state interests in preserving "a fair bargaining process." 241

It is not clear to me that this alternative perspective is ultimately coherent, because interests in preserving a fair bargaining process are necessarily paternalistic. They presuppose that consumers are vulnerable and dependent, and these assumptions conflict with the autonomy that public discourse must ascribe to citizens. ${ }^{242}$ A thorough assessment of the adequacy of this alternative vision, however, should be put off to the day when its precise dimensions

240. See 44 Liquormart, 517 U.S. at 502 (Stevens, J.) (joined by Kennedy, J. and Ginsburg, J.) (quoting Cincinnati v. Discovery Network, Inc., 507 U.S. 410, 426 (1993)); see also id. at 522 (Thomas, J., concurring).

241. Id. at 501; cf. Discovery Network, Inc., 507 U.S. at 428-31.

242. For a full discussion, see Post, Meiklejohn's Mistake, supra note 25, at 1128-33. It would be quite inconceivable, for example, to regulate "misleading" political speech within public discourse on the grounds that citizens are not autonomously capable of evaluating speech for themselves and hence need protection from potential deception. Within public discourse, persons are presupposed to be independent and autonomous. If commercial speech were to be redefined as a variant of public discourse, such independence and autonomy would also have to be ascribed to consumers. 
and structure become more visible. For the moment I wish only to observe that a principled exposition of this perspective would require deep and substantial modifications to existing commercial speech doctrine.

The alternative vision implies, for example, that the First Amendment could no longer countenance compelled disclosures within the realm of commercial speech. If commercial speech were conceptualized as an effort of citizens to render the state responsive to them, compelled commercial speech would compromise the basic independence of citizens. Nor could the Court any longer tolerate regulations of commercial speech that were significantly more overinclusive than those accepted within public discourse. The same precision of regulation would be applicable to both. Nor could the misleading requirement any longer be employed, even in the limited form that 1 have suggested is compatible with a Meiklejohnian perspective. ${ }^{243}$

The Court thus seems to be working its way toward a fundamental choice. It can either continue the task of fashioning doctrine on the assumption that the First Amendment safeguards the informational function of commercial speech, or it can overturn its prior doctrinal structure and remake commercial speech doctrine as though it were protecting participation within the process of self-government. I do not think that the Court has thoroughly canvassed the enormous implications of the latter alternative. One might perhaps interpret the tentative speculation of some Justices concerning the lack of a normative boundary between commercial speech and public discourse as expressing their frustration at the manifest inadequacies of the Central Hudson test, rather than as indicating a serious commitment to fundamentally reevaluating the significance and regulatory framework of commercial speech.

My purpose in this Lecture has been to demonstrate that the major outlines of contemporary commercial speech doctrine can be explained by reference to a roughly Meiklejohnian perspective, so that the Central Hudson test can in fact be subject to principled revision. This revision would require the test both to articulate which government purposes are acceptable and which are not, and to specify which impacts on commercial speech are acceptable and which are not. It would also require that the misleading require-

243. I mention in text only revisions in those aspects of commercial speech doctrine that 1 have already discussed in this Lecture. Other revisions would also be necessary. For example, most regulations of commercial speech are content based. The constitutionality of such regulations would present significant problems if commercial speech were conceptualized as a form of public discourse. Moreover, if the flimsy claims propagated by the Court about the unique durability and verifiability of commercial speech are not credited, the Court would also have to apply to commercial speech the same chilling-effect analysis that it presently applies to public discourse. 
ment be employed only in a restricted way that refers to the structural relationship between consumers and speakers.

Such revision would not, however, precipitate a total reconstruction of the contemporary doctrinal framework of commercial speech. It would preserve the distinction between commercial speech and public discourse, and it would explain why the latter has always received different and greater constitutional protections than the former. If these advantages are attractive to a majority of the Court, commercial speech doctrine, as we now know it, may just survive its present vicissitudes, as it has precariously survived those of the past. 
$* * *$

HeinOnline -- 48 UCLA L. Rev. 58 2000-2001 